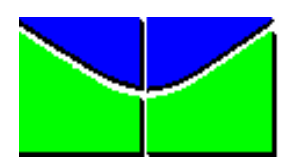

Universidade de Brasília

Centro de Excelência em Turismo

\title{
O ECOMUSEU DO CERRADO: UM INSTRUMENTO PARA O ECOTURISMO NO BRASIL CENTRAL
}

\author{
ALCIDEA COELHO COSTA \\ MANOEL CLÁUDIO DA SILVA JÚNIOR \\ Monografia apresentada ao Centro de \\ Excelência em Turismo da \\ Universidade de Brasília como \\ requisito parcial para obtenção do \\ certificado de Especialista em \\ Ecoturismo.
}

Brasília, DF, agosto de 2004 
UNIVERSIDADE DE BRASÍLIA

Centro de Excelência em Turismo

Curso de Especialização em Ecoturismo

\title{
O ECOMUSEU DO CERRADO: UM INSTRUMENTO PARA O ECOTURISMO NO BRASIL CENTRAL
}

\author{
Alcidea Coelho Costa
}

Banca Examinadora

\author{
Manoel Cláudio da Silva Júnior, Ph.D. \\ Orientador \\ Lourdes M. Bandeira, Dr . \\ Membro da Banca
}

Brasília, DF, 02 de agosto de 2004 
COSTA, ALCIDEA COELHO

O Ecomuseu do Cerrado: um instrumento para o ecoturismo no Brasil

Central/Alcidea Coelho Costa - - Brasília, 2004.

91p.

Monografia (Especialização) - Universidade de Brasília. Centro de Excelência em Turismo. Brasília, 2004.

Área de concentração: Ecoturismo

Orientador: Manoel Cláudio da Silva Júnior

1. Turismo 2. Ecoturismo 3. Ecomuseu. - Monografia 
ALCIDEA COELHO COSTA

\section{O ECOMUSEU DO CERRADO: UM INSTRUMENTO PARA O ECOTURISMO NO BRASIL CENTRAL}

Manoel Cláudio da Silva Júnior, Ph.D.

Orientador

Lourdes Bandeira, $\mathrm{Dr}^{\mathrm{a}}$.

Membro da Banca

Tânia Montoro, Dr ${ }^{\mathrm{a}}$.

Membro da Banca

Brasília, DF, 02 de agosto de 2004 


\title{
DEDICATÓRIA
}

\author{
A Deus, \\ aos meus pais, \\ esposo, \\ filhos, \\ irmãos, \\ amigos, \\ professores
}

e a vida. 


\section{AGRADECIMENTOS}

Às pessoas e instituições que contribuíram para a realização deste trabalho:

Manoel Cláudio da Silva Júnior

Laís Aderne

Ecomuseu do Cerrado

Milton Goes

Amigos

Centro de Excelência em Turismo - UNB

Secretaria de Meio Ambiente e Turismo de Pirenópolis/GO 


\section{O Ecomuseu do Cerrado: um instrumento para o Ecoturismo no Brasil Central}

\section{Resumo}

O ecoturismo no Brasil Central, significa ter ainda um grande campo a ser especulado, tendo a premissa do espírito de conservação e preservação dos recursos naturais do lugar a ser implementado, como também, respeitando a cultura do seu povo. A partir destes princípios foi analisado o Ecomuseu do Cerrado (Estado de Goiás), por meio de pesquisa bibliográfica, entrevistas com a coordenadora professora Laís Aderne em anexo B páginas 87 a 90 e o professor Manoel Cláudio da Silva Júnior e visita in loco aos municípios de Pirenópolis, Corumbá, e Santo Antônio do Descoberto. O estudo constatou que na área do Ecomuseu pode ser implantada essa atividade econômica, mesmo com todas as dificuldades que passam os pequenos locais do Brasil. Sendo muitas vezes as iniciativas desestimuladas pela falta de recursos financeiros, pessoais e instrumentais, que as impossibilitam de serem realizadas, o Ecomuseu do Cerrado, ainda assim, promove a participação da comunidade nos seus municípios, como também incentiva o envolvimento de órgãos institucionais buscando o desenvolvimento sustentável. Foi verificado a importância de se ter um museu considerado moderno, por ser um museu aberto e flutuante, dentro de uma área territorial total de 8.066 $\mathrm{Km}^{2}$, com população em torno de 234.692 (censo IBGE 2000), nos municípios que o compõem (Abadiânia, Águas Lindas, Alexânia, Cocalzinho, Corumbá, Pirenópolis e Santo Antônio do Descoberto), para uma constante reflexão e conseqüentemente, em permanente alteração, reconhecendo que seu processo será sempre dinâmico, no sentido de recriação, caracterizando as ações humanas que o estão construindo e reconstruindo em cada momento da sua história, permitindo intercâmbio, enriquecimento e o exercício da cidadania. 


\title{
THE SITE MUSEUM IN CERRADO: ON INSTRUMENT TO THE ECOTOURISM IN THE CENTRAL REGION OF BRAZIL
}

\begin{abstract}
The ecotourism in the Central region of Brazil means to have a great field to be investigated, having as a premise the spirit of conservation and preservation of natural resources for the place where ecotourism will be implemented as, also, considering the culture of its folk. The ECOMUSEUM OF CERRADO was analysed (State of Goiás), by mean of a bibliographic research, interviews with Laís Aderne coordenate and Manoel Cláudio da Silva Júnior teacher and visits "in loco" in the districts of Pirenópolis, Corumbá and Santo Antônio do Descoberto. The study verified that in the area of the SITE MUSEUM the economic activity can be implemented, even with all the difficulties that occur in the small places of Brazil. Sometimes these experiences are unencourage that are impossible to be done due to the lack of economic, personal and instrumental resources. The ECOMUSEUM OF CERRADO promotes the participation of the community in its districts, as well it simulates the concerning of institutional organ, searching for the sustainable, development. It was verified the importance of having a museum considered as modern, because it is an open museum and floating, inside an territorial area of $8.066 \mathrm{~km}^{2}$, with population around of 234.692 (census IBGE 2000), in the districts that compound it (Abadiânia, Águas Lindas, Alexânia, Cocalzinho, Corumbá, Pirenópolis and Santo Antônio do Descoberto), to promote a reflexion and, as consequence, in permanent changing, recognizing that its process will be always dynamic, in sense of recreation, characterized the human actions that are building it and rebuilding in each moment of its history, allowing the interchange, enrichment and the exercise of the citizenship.
\end{abstract}




\section{SUMÁRIO}

Página

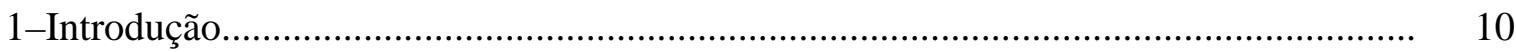

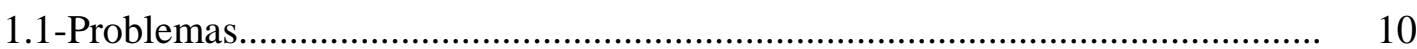

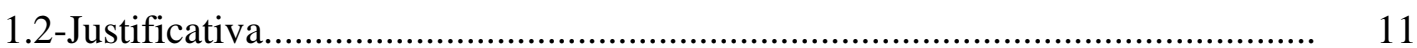

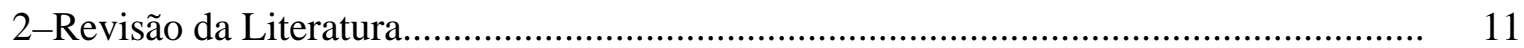

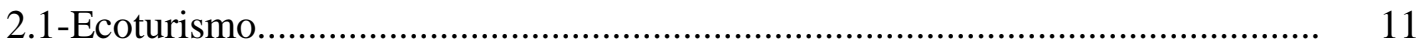

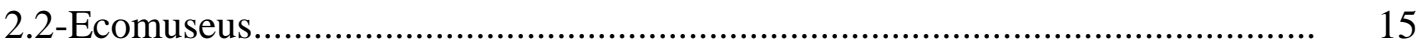

2.3 - O Ecomuseu do Cerrado.................................................................................. 21

2.3.1 - Características da região do Ecomuseu do Cerrado............................. 24

2.3.1.2 - Relatório por Município................................................................... 26

3 - Biodiversidade do Cerrado.................................................................................. 60

3.1 - Uso e Ocupação 70

3.2 - Legislação Ambiental.................................................................................. $\quad 74$

4 - Ecologia Profunda - um novo paradigma.............................................................. 76

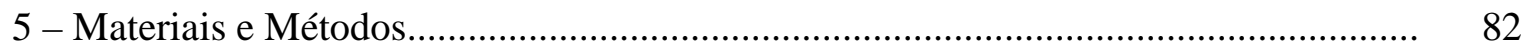

6 - Resultados e Discussão................................................................................ 82

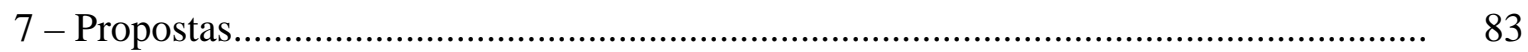

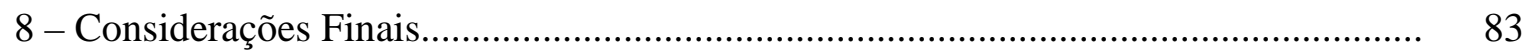

9 - Referências Bibliográficas............................................................................. 85

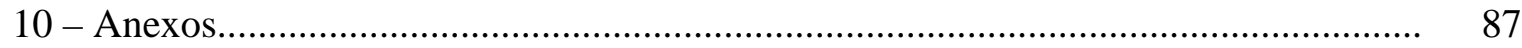




\section{1-Introdução}

O Ecomuseu do cerrado se apresenta como proposta de preservação ambiental e cultural do Cerrado, no Planalto Central e visa contribuir como instrumento de valorização e reconstrução de identidade cultural e do patrimônio ambiental em localidades e comunidades desse bioma, que já sofre, num ritmo acelerado, as degradações e destruições, principalmente com o incentivo da cultura da soja.

A preocupação em conservar e preservar os recursos naturais e a cultura local permite a criação de medidas que possibilitem destinar estudos, pesquisas, programas de lazer, entretenimento que incorporem valores, de forma ética, para implementação de uma nova prática de museu vinculado ao meio ambiente e sua sustentabilidade. Nesse contexto insere-se a prática do Ecoturismo.

O Ecomuseu promove a relação entre a sociedade civil e instituições governamentais, objetivando o crescimento sócio-econômico, político e suas multi-conexões de forma participativa e responsável para a localidade. Permite também o resgate da memória, tradições, saberes e fazeres da cultura, no local de sua implementação.

Portanto, esse trabalho propõe uma análise dos potenciais e problemas levantados pelo projeto Ecomuseu do Cerrado para avaliar suas condições como instrumento para a prática do Ecoturismo.

\section{1-Problemas}

Com a descaracterização da cultura e do ambiente natural do cerrado, faz-se necessário o resgate tanto das tradições e dos saberes, como também, da vegetação, do clima, dos recursos 
hídricos e de todos os componentes ambientais desse bioma. Dessa forma, estará o Ecomuseu do Cerrado preparado para o resgate desses princípios?

O Ecomuseu do Cerrado poderá oferecer alternativas para o Ecoturismo no Brasil Central?

Dentro dos padrões e normas das atividades ecoturísticas, o Ecomuseu do Cerrado pode ser enquadrado como uma opção de entretenimento e lazer?

\section{2-Justificativa}

O Ecomuseu do Cerrado é composto por sete municípios: Abadiânia, Alexânia, Águas Lindas de Goiás, Cocalzinho, Corumbá, Pirenópolis (sede) e Santo Antônio do Descoberto do Estado de Goiás, todos localizados no entorno do Distrito Federal. Nesses municípios O Ecomuseu está trabalhando para a implementação de hortos florestais, hortas e herbários com plantas medicinais, resgate da história da região e de seus fazeres culturais, pontos de atração turística, trilhas interpretativas, educação ambiental, reservas florestais, Museu de História Natural, dentre outras propostas que envolvem em processo de educação e desenvolvimento sustentável.

Dessa forma, busca oferecer condições básicas para estabelecer em programa de ecoturismo, que apóie economicamente no resgate de um desenvolvimento sustentável da região, que perdeu seu poder econômico com o término do período aurífero do garimpo e da criação de gado da região.

O objetivo do presente trabalho foi discutir o potencial do Ecomuseu do Cerrado para o Ecoturismo, para conservação do Bioma Cerrado e conseqüentemente como um instrumento para a transformação da ecologia interior dos moradores da região.

\section{2-Revisão da Literatura}




\section{1-Ecoturismo}

Em todo o mundo e especialmente nos países da Europa, é comum a visitação de pessoas em locais em que a natureza possa ser apreciada. Esses lugares se tornaram escassos devido ao crescimento das cidades, com o aumento de contigente populacional e com o processo da industrialização, restando áreas naturais reservadas, somente em "Parques Naturais". Esses espaços que ainda existem, são considerados potenciais ecológicos significativos. Já a cultura, é uma fator de relevância nesses países, pois é tratada com afinco e seriedade, sendo repassada por gerações a gerações por meio das tradições e dos fazeres, enraizadas nas famílias, e trabalhadas desde a infância.

Nesses países, as pessoas tem o hábito de passear em museus, nos quais são considerados atrativos turísticos tanto nacionalmente como internacionalmente. Também é um local que são repassadas informações que irão acrescentar na educação das crianças, adolescentes e adultos, porque esses, são vistos como um lugar em que podem ser mostrado o patrimônio antigo e fazer ligação com o patrimônio presente, tanto para os recursos naturais como para os culturais.

“Conforme o que se trata na Europa, o patrimônio em geral são o atrativo/recurso turístico por excelência. Os museus transformaram-se durante o século XX, deixaram de ser apenas depósitos de coisas velhas para mostrar seus objetos e fazer chegar sua mensagem ao público de uma forma dinâmica e até lúdica em que muitas das técnicas dos parques temáticos são utilizadas, assim como recursos de multimídia e outros recursos tecnológicos. Com esse novo perfil, o museu passou a ser complemento necessário do turismo, superando preconceitos de ambas as partes.” (Azevedo, 2002, p.176)

No Brasil as discussões sobre essa nova modalidade de turismo são recentes. O Ecoturismo é considerado uma das áreas do turismo voltado para a integração do homem com a natureza. Permite que o homem participe da criação de sua história, de sua língua, da expressão artística, como também na formação do potencial econômico e melhorias para a comunidade local.

Esse é um novo paradigma, que visa sensibilizar os visitantes com novas experiências, principalmente nas demonstrações culturais da região com trabalhos mostrados nos 
artesanatos, na culinária e com a educação ambiental, que são pontos a serem tratados no ecoturismo.

"Novos meios estimulam os municípios a gerarem métodos que garantem uma posição espacial de roteiro ecoturístico. Para tanto é de fundamental importância, preservar o que já existe na consolidação da cultura local, utilizando como ferramenta de sucesso, a sensibilidade do turista em cultuar as belezas cênicas, como também, as formas de expressão da cultura e dos recursos naturais existentes. Assim, para a realização e desenvolvimento das práticas do ecoturismo, não se deve perder de vista a sustentabilidade.” (Azevedo, 2002, p. 176)

"Um princípio que vem sendo aplicado ao planejamento do turismo de natureza deve ser aplicado ao planejamento do turismo com base no legado cultural: a sustentabilidade. Isso implica respeitar a capacidade de carga, conceito também surgido em relação a atrativos naturais.” (Barretto 2003, p. 77).

A partir dessa percepção, as “Diretrizes para uma Política Nacional de Ecoturismo”, de 1994, o Instituto Brasileiro de Turismo-EMBRATUR, órgão federal vinculado ao Ministério do Turismo e o Instituto Brasileiro de Meio Ambiente e dos Recursos Naturais Renováveis IBAMA, adotaram a seguinte definição para o ecoturismo:

"Um segmento da atividade turística que utiliza, de forma sustentável, o patrimônio natural e cultural, incentiva sua conservação e busca a formação de uma consciência ambientalista através da interpretação do ambiente, promovendo o bem-estar das populações envolvidas.” (EMBRATUR, 1994)

\section{Conforme Fennell:}

"O Ecoturismo cresceu como uma conseqüência da insatisfação com as formas convencionais de turismo que, num sentido geral, ignoraram os elementos sociais e ecológicos de regiões em países estrangeiros, em favor de um enfoque mais antropocêntrico e concentrado estritamente no lucro dos produtos de turismo oferecidos.” (Fennell, 2002, p.41)

\section{Para Goodwin, o ecoturismo é:}

"O turismo de natureza, de baixo impacto, que contribui à manutenção de espécies e habitats diretamente, por meio de uma contribuição à conservação e/ou indiretamente produzindo rendimentos para as comunidades locais, para que elas valorizem e, portanto, protejam suas áreas herdadas de vida selvagem como fonte de renda." (Goodwin, 1996, p. 288)

De acordo com a autora Ziffer, o ecoturismo é conceituado da seguinte forma: 
"Uma forma de turismo inspirada principalmente na história natural de uma área, inclusive de suas culturas nativas. O ecoturista visita áreas relativamente não-desenvolvidas com o espírito de apreciação, participação e sensibilidade. O ecoturista utiliza os recursos naturais e de vida selvagem de forma não predatória e contribui para a área visitada por intermédio de meios financeiros ou com seu esforço pessoal com o objetivo de beneficiar diretamente a conservação do local e o bem-estar econômico dos habitantes. A visita deve fortalecer a conscientização do ecoturista e a sua dedicação às questões de conservação em geral e às necessidades específicas dos habitantes locais. O ecoturismo também pressupõe a prática de uma gestão pelo país ou região anfitriã, que se compromete a planejar e manter os locais com a participação dos habitantes locais, realizando um marketing apropriado, reforçando os regulamentos e usando os lucros do empreendimento para investir na gestão da área e no desenvolvimento da comunidade.” (Ziffer, 1989, p.6)

Para Wallace e Pierce, a definição de ecoturismo é:

"A viagem a áreas naturais relativamente intocadas, para o estudo, o divertimento, ou a assistência voluntária. É a viagem em que há preocupação com a flora, a fauna, a geologia e os ecossistemas de uma área, assim como com as pessoas (guardiãs) que vivem nas vizinhanças, suas necessidades, sua cultura e seu relacionamento com a terra. O ecoturismo encara as áreas naturais como "a casa de todos nós" num sentido global (“eco” significando "casa”), mas também especificamente a "casa dos habitantes das vizinhanças”. Ele é visto como uma ferramenta para a conservação e o desenvolvimento sustentável, especialmente nas áreas onde a população local é solicitada a abrir mão do uso predatório dos recursos naturais em favor de outros tipos de uso.” (Wallace e Pierce, 1996, p.848)

Para Rambaldi e Ferreira (Faria, 2001 apud Rimbaldi e Ferreira, 2000), no ecoturismo pode acontecer alguns entraves para o desenvolvimento do setor, tais como:

"À ausência de consenso sobre sua conceituação e a falta de critérios, regulamentos e incentivos que orientem empresários, investidores e o próprio governo, propiciando uma coexistência harmônica entre exploração e conservação. Para sobrepujar tais obstáculos e alcançar os objetivos a que se destina, são necessários uma abordagem multidisciplinar e um sistema intersetorial, um planejamento cuidadoso (tanto físico como gerencial para impedir que a atividade seja impulsionada, exclusivamente, por forças do mercado) e diretrizes e regulamentos rígidos, que garantam estabilidade à atividade.” (Rambaldi e Ferreira, 2000, p. 20)

Essa tendência a esse novo segmento no turismo, o ecoturismo, vem sendo crescente e despertando para o contato direto com ambientes naturais, em que passam ser produtos consumidos por meio da visitação no local. Mas, deve-se ter toda cautela para não impactar o ambiente e conseqüentemente ter o cuidado para não danificar áreas de relevância natural e cultural. 
Todas as definições se complementam, cada qual fortifica o posicionamento do ecoturista que visa em se preocupar com o meio ambiente e com a comunidade envolvida. Mas a definição de ecoturismo que mais se adequa a proposta de trabalho, é a que é apresentada por Ziffer.

\section{2-Ecomuseus}

Para a sustentabilidade na relação do homem com o meio em que se vive, faz-se necessário o surgimento de alternativas que possam contribuir para ilustração da tradição, do fazer e do saber, como também, a utilização dos recursos naturais disponíveis de forma responsável, no local de implementação de projetos de ecomuseus.

Para valorizar a identidade e diversidade cultural no turismo e a participação da comunidade, o ecomuseu pode ser uma proposta que vincula o trabalho, como uma alternativa de atividade econômica, mas sem perder de vista também, a valoração dos patrimônios natural e cultural do local onde será implantada a atividade ecoturística.

Para Barretto (apud Hudson, 1987, p.144) o conceito de ecomuseu é:

“Uma expressão inglesa, site museums, que pode ser traduzida de duas formas: como "museu de sítio" ou como “museu no local”. Sendo que, a primeira tradução, limita um pouco o conceito a museu de sítio arqueológico, o que não corresponde à definição do Conselho Internacional de Museus - Icom para esse tipo de museu: Museu concebido e implantado para proteger a propriedade natural ou cultural, móvel ou imóvel, em seu local original, ou seja, preservada no local em que tal propriedade foi criada ou descoberta.” (Barretto, 2002, apud Hudson, 1992, p.144)

Ainda pela citação de Barretto (apud Hudson, 1992, p.29), afirma que:

"Existem quatro tipos de site museums: ecomuseu, etnográfico, histórico e arqueológico, sendo que na proposta original, a diferença básica entre um site museum e um ecomuseu estão na administração e no escopo da preservação cultural. Os ecomuseus propõem uma administração compartilhada entre autoridades e comunidade local, na qual as autoridades aportariam os experts.” (Barretto, 2002, apud Hudson, 1992, p.29) 
A história e a origem de ecomuseus, segundo Barretto (apud Hudson, 1992, p.28), relata como surgiu à idéia e onde iniciou os primeiros no mundo:

"O pioneiro do site museums (e também dos museus - jardim) foi o Farnham, em Dorset, na Inglaterra, implantado numa propriedade herdada por Pitt Rivers (nome verdadeiro era August Hanry Lane Fox) em 1880, na qual ele realizou escavações durante os 20 anos subseqüentes.

Esse tipo de museu teria tido suas bases assentadas, em meados da década de 1950, quando Georges Henri Rivière, considerado o pai da nova museologia francesa, planejou o Museu Bretão de Rennes. Rivière definia o ecomuseu como "um instrumento concebido, moldado e operado conjuntamente pelo público (autoridades e população local)”... É um espelho onde a população local vê a si própria para descobrir sua imagem e no qual procura uma explicação para o território do qual faz parte... É um espelho que a população mostra aos visitantes para melhor ser compreendida, de forma que sua indústria, seus costumes e sua identidade inspirem respeito. Coloca o ser humano em seu ambiente natural. Retrata a natureza tanto na sua condição selvagem, quanto nas adaptações provocadas pela sociedade tradicional e industrial.

O primeiro ecomuseu constituído com esse nome foi o de Le Creusot, mas, experiências pioneiras aconteceram em Marquèze e Camargue.

O Museu de Marquèze, em princípio um museu ao ar livre, está localizado no Parque Nacional da Gasconha, na França, e segue o modelo de Skansen: foram trazidas casas de madeira e gado, que juntamente com o artesanato e o equipamento agrícola utilizado até poucos anos antes, mostravam ao visitante um retrato do passado e das mudanças acontecidas no meio ambiente.

O Museu de Camargue está no Parque Regional homônimo e sua finalidade primeira era mostrar aos turistas a originalidade e a riqueza natural e cultural do Camargue, assim como necessidade de protegê-las e conservá-las. Toda essa informação deveria ser dada aos visitantes por pessoas da comunidade, que deveriam sentir que aquele era seu museu.

O ecomuseu de Le Creusot (França) surgiu unindo os ideais de G. H. Rivière e H. de Varine. Em princípio, serviria como terapia para elevar o moral e criar novas fontes de trabalho num distrito que tinha sido, a partir do século XVIII, uma das regiões mais prósperas da França. Ali tinha se estabelecido indústria de armas e locomotivas da família Schneider, que após colaborar com os nazistas, faliu, levando à falência a região toda, constituída por vários municípios.

O ecomuseu ocupou uma área de $500 \mathrm{Km}^{2}$, metade urbana e metade rural, com 150 mil habitantes e duas comunidades, Le Creusot e Montcleau-les-Mines, e, nessa área, toda planta, todo animal, e todo objeto eram considerados patrimônio. Era um "museu estilhaçado", em cujo centro estava o castelo antes ocupado pela família Schneider, onde eram guardadas coleções de objetos que contavam a história local.

O pessoal desse museu era composto por um corpo permanente de profissionais e de técnicos, pesquisadores, animadores culturais, entre outros, que deviam morar junto com a comunidade e interagir com ela. A comunidade participava dando idéias sobre a programação. Por diversas razões, a experiência não durou muito: "Le Creusot" teve oito anos dourados. Por volta de 1986, estava virtualmente em colapso... porém (durante seu período inicial) funcionou como um dos mais produtivos laboratórios experimentais de museologia do século. 
Apesar do desaparecimento da proposta inicial, a filosofia original do ecomuseu constituiu a maior inovação dos últimos 50 anos, e contribuiu para melhorar a proposta de muitos museus ao ar livre. Deixou a semente da idéia de que os museus podem ser fóruns de discussões dos problemas do presente.” (Barretto,2002, p.61)

Segundo Barretto (2002, p.61), em 1996, Varine-Bohan preferiu designar ecomuseu como um museu comunitário, e o descreveu como um processo cultural identificado, com uma população, num determinado território, que utilizou um legado cultural comum para seu desenvolvimento.

Além disso, um ecomuseu, considerado como "um instrumento de turismo de tradição, ou baseado no legado cultural, deve ter como principal atrativo o patrimônio natural e o patrimônio cultural, sendo esse, ampliado à medida que se revisa o conceito de cultura.” (Barretto, 2003, p.29)

Ainda na afirmação e análise de Barretto (2003, p.11), “o patrimônio cultural é muito mais amplo, pois inclui não apenas os bens tangíveis como também os intangíveis, por isso o conceito "legado cultural” parece mais adequado do que "patrimônio" porque engloba todo o ser humano e todas as manifestações artísticas.”

A Unesco em 1972, na Convenção do Patrimônio Mundial, definiu patrimônio cultural como:

*Monumentos: obras de arquitetura, esculturas e pinturas monumentais, elementos ou estruturas de natureza arqueológica, inscrições, cavernas e combinações destas que tenham um valor de relevância universal do ponto de vista da história, da arte ou das crenças;

*Conjunto de edificações: conjuntos de edificações separados ou conectados, os quais, por sua arquitetura, homogeneidade ou localização na paisagem, sejam de relevância universal do ponto de vista da história, da arte ou das ciências;

*Sítios: obras feitas pelo homem, ou pela natureza e pelo homem em conjunto, e áreas que incluem sítios arqueológicos que sejam de relevância universal do ponto de vista da história, da estética, da etnologia ou da antropologia. 
Conforme Barretto (2003, p.13), “uma das advertências da convenção de 1972 foi estar o patrimônio cultural cada vez mais ameaçado de destruição, tanto pela deterioração normal, decorrente de fatores naturais, como por mudanças nas condições econômicas e sociais, que agravam a situação, e dentre as quais estaria o turismo.”

Além de todas essas conceituações, é importante frisar como melhor proceder na utilização dos patrimônios, para não ameaçá-los de algum prejuízo, que por ventura possa acontecer. Assim:

"Para proteger o patrimônio dessas ameaças, são necessárias políticas de preservação. Preservação significa proteger, resguardar, evitar que alguma coisa seja atingida por alguma outra que lhe possa ocasionar dano. Conservar significa manter, guardar para que haja uma permanência no tempo. Desde que guardar é diferente de resguardar. Preservar o patrimônio implica mantê-lo estático e intocado, ao passo que conservar implica integrá-lo no dinamismo do processo cultural. Para o patrimônio, a melhor opção é a conservação, pois permitem viabilizar economicamente a manutenção dos bens culturais móveis ou imóveis, e fundamentalmente a utilização dos bens como equipamentos turísticos, o que implica também, transformá-los em museus, mas dentro das propostas novas, em que os museus sejam equipamentos capazes de despertar o interesse na visitação por parte dos turistas."

"Nesses locais, as atividades museológicas transcorrem em forma de encenações do cotidiano de um determinado momento histórico escolhido para ser congelado no tempo, dentro de um espaço delimitado em razão dos vestígios preservados (prédios, ruas, casas, etc.). Isso só é possível se, previamente, houve um trabalho de restauração do patrimônio, seguido de sua ressignificação e de sua utilização no presente com finalidade didático-pedagógica e cultural. Além do óbvio benefício que traz para a comunidade, existe o benefício econômico oriundo da vinda de numerosos turistas, milhões por ano, atraídos por esse tipo de proposta diferenciada tanto na área museológica como na área turística propriamente dita” (Barretto, 2002, p.39)

\section{A história dos ecomuseus iniciou-se na Europa:}

"A Inglaterra foi o país pioneiro na parceria bem sucedida entre museus e turismo, parceria que permite a sustentabilidade econômica dos museus e a prática do turismo histórico sustentado... Os sites museums, são a grande atração turística na Inglaterra. O trabalho realizado pelo National Trust naquele país, na gestão do patrimônio cultural, está sendo considerado um modelo em todo o continente europeu. Em segundo lugar, como paradigma de gestão de patrimônio, está a Austrália.

Dentre todos os museus, os que mais sucesso têm tido como atração turística têm sido, pela ordem, os sites museums e os museus ao ar livre. Esse tipo de museu teve grande aceitação por parte do público, pois reúne, ao mesmo tempo, a rigorosa pesquisa científica, a contextualização histórico-temporal e espacial e o elemento do prazer estético e paisagístico, pois normalmente, as exposições são realizadas de forma muito acessível, não raro possibilitando ao visitante o contato direto com os objetos e suas funções. Por estar em grandes extensões de terreno, permitem atividades de descontração e contato com a natureza. 
Parte do sucesso dos museus de sítio e dos museus ao ar livre reside no fato de que eles estão em áreas agradáveis, como museus-jardim, e, estando fora dos centros urbanos, são visitados por pessoas realmente interessadas. Para chegar a esse tipo de museu, é necessário deslocar-se, planejar uma pequena viagem e estar disposto a passar várias horas no local. O público que o visita, portanto, é composto por pessoas realmente interessadas, pois esses não são lugares de passagem, nos quais se entra porque não se tem o que fazer, nem para levar crianças em dias de chuva, na falta de outras opções.

Os sites museums começaram na Europa e foram adotados imediatamente nos Estados Unidos, onde se transformaram em sucesso comercial. No mundo inteiro, têm-se multiplicado muito mais do que os museus tradicionais, porque a auto-sustentação é mais fácil, em conseqüência de sua grande aceitação por parte do público. Essa aceitação reside basicamente no fato de que a aura histórica dos objetos não foi criada por técnicas museológicas: ela simplesmente está no local. Isso tem levado à afirmação de que a visita aos sites museums tem algo de peregrinação medieval, quando visitavam lugares sagrados em que aconteceram fatos religiosos relevantes. Voltando às idéias de Benjamim, os locais teriam aura porque seriam autênticos e não reproduções.

Há atualmente site museums em antigos campos de concentração da Europa, em Hiroshima e Nagasaki, no Japão; no cruzador Aurora, em que começou a revolução de outubro em São Petersburgo (Leningrado entre 1924 e 1991). No Canadá está a cabana do Tio Tom (na verdade, reverendo Josiah Henson); na Argentina, a casa em que viveu o poeta Pablo Neruda; em Havana, a casa de Ernest Hemingway, só para citar alguns. O site museum mais conhecidos nos Estados Unidos, e também o pioneiro em seu gênero, é Williamsburg, na Virgínia, em cujo centro histórico há encenações permanentes do cotidiano do país do século XVIII, mostrando a vida de todos os grupos sociais, incluindo os negros e os brancos menos privilegiados. Também há oficinas, nas quais são realizados, na frente do público, trabalhos como, por exemplo, a construção de móveis da época. Grande parte dos sites museuns dos Estados Unidos tem guias e monitores vestidos a caráter, sistema que vai sendo, aos poucos, adotados na Europa.

Atualmente, o site museums mais importante do mundo e uma das maiores atrações turísticas culturais é Ironbridge George, na Inglaterra, que se estende ao longo do rio Svern, onde foi construída a primeira ponte de ferro do mundo em 1799. Foi o primeiro museu europeu a combinar a prática museológica com conceitos de rentabilidade e retorna de capital que, até os anos 70, eram tabu na área museológica. O seu diretor acreditava que o museu deveria ser suficientemente atrativo para motivar as pessoas a se deslocar até ele, e lá deveriam ter, de um lado, boa exposição e, de outro, boa infra-estrutura (banheiros, estacionamentos), assim como funcionários eficientes tanto na atenção quanto no conhecimento.” (Barretto, 2002, p.41)

\section{Para a autora Azevedo (2002, p.176), em seu artigo Educação, Turismo e Enraização de} propostas turísticas, aponta o ecomuseu como:

“Uma alternativa de organização de localidades que buscam sintonia com o quadro contemporâneo e que já dispõem de uma trajetória socioeconômica significativa, como é o caso do município da Santa Maria Madalena (Centro-Norte Fluminense, no Brasil). Se o ecomuseu for temático ou não, exigirá estudo de viabilidade, planejamento de exposições, propiciará aproveitamento de mão-de-obra local, restauração de peças, esquemas de 
animação, criando novas oportunidades de trabalho e novas exigências de preparação profissional. Com atividades permanentes, ocasionais e mesmo itinerantes, o ecomuseu passa a constituir um instrumento também para circulação de bens culturais, com destinação possível a públicos diferenciados. É uma atividade turística de curta duração, convém que ela se acoplem outras iniciativas que motivem permanência mais longa dos turistas.”

Entretanto, para melhor aproveitamento de ecomuseus como um potencial turístico microrregional, não perdendo a essência da realidade local e evitando a descontinuidade do processo cultural natural, o movimento descentralizador do turismo para o interior, têm os municípios como a menor unidade federativa representativa em nosso país, uma busca de descobrimento e ou redescobrimento de uso de métodos que possam fortalecer a auto estima de comunidades locais que, em todo momento, sofre de desfiguração. Portanto o ecomuseu deve ser uma saída, utilizando o processo pedagógico como ferramenta para a revitalização em áreas muitas vezes adormecidas.

Esses conceitos concordam com pontos específicos citados para os ecomuseus, assim pode-se justificar o planejamento do turismo em ecomuseus que vise possibilitar a garantia da perpetuidade da natureza e da cultura. Que trate o visitante como participante do processo da estruturação e organização no interior dos ecomuseus, mas que tenha também, uma postura critica em relação ao mundo no que se pretende mostrar.

Em maio de 2004, foi criado a nível federal o Sistema Brasileiro de Museus assinado pelo presidente Luiz Inácio Lula da Silva e pelo Ministro da Cultura Gilberto Passos Gil Moreira, que dispõe no uso das atribuições que conferem os incisos IV e VI do artigo 84, da Constituição. Decreta no Art. $3^{\circ}$ - Integram o Sistema Brasileiro de Museus as instituições museológicas de administração pública federal, vinculadas a Poder Executivo. No $\S 1^{\circ}$ Poderão fazer parte do Sistema Brasileiro de Museus, mediante a assinatura de instrumento legal formalmente estabelecido com o Ministério da Cultura, as seguintes instituições: inciso IV, diz que, as organizações sociais, museus comunitários, ecomuseus e os grupos étnicos e culturais que mantenham ou estejam desenvolvendo projetos museológicos;

Decreta também no Art. $4^{\circ}$ - Constituem atribuições do Sistema Brasileiro de Museus: inciso $\mathrm{V}$, estimular a participação dos diversos segmentos da sociedade, inclusive da iniciativa 
privada, de museus comunitários, ecomuseus, museus locais, museus escolares e outros, reforçando os interesses na viabilização e manutenção dos objetivos do Sistema.

Visto que na legislação brasileira, no Sistema Brasileiro de Museus, já se faz menção e referência aos ecomuseus como uma Instituição Museológica, compreendida em práticas sociais e colocadas a serviço da sociedade e de seu desenvolvimento, tendo comprometimento com a gestão democrática e participativa.

Portanto, com a legitimação de ecomuseus no Sistema Brasileiro de Museus, significa a conquista na sua representatividade e garantindo a melhoria nos trabalhos que possam ser realizados, tanto para a sociedade como também para as instituições que o desempenha.

\section{3-O ECOMUSEU DO CERRADO}

O Ecomuseu do Cerrado nasceu de uma proposta em Brasília no ano de 1989, a partir da Coordenação de Museus da Secretaria de Cultura do Distrito Federal que tinha um propósito de preservação do vale localizado em Samambaia, Taguatinga e Ceilândia uma área onde as características originais do ecossistema ainda eram marcantes e encontrava-se vegetação abundante e diversificada, fauna significativa e veredas. Nessa região foram encontrados sítios arqueológicos e foi a partir daí, que surgiu a proposta de se criar um museu arqueológico no local.

A idéia de um museu, com propostas modernas, em que o homem, sua cultura e a natureza que o envolve, possa ser representado como um espelho. Assim, surgiu a idéia de se criar um ecomuseu. Foi quando em 1997, por meio de uma organização não governamental o Instituto Huah, reuniu alguns profissionais envolvidos para dar início ao projeto original.

O Ecomuseu do Cerrado é um museu aberto, descentralizado, oferece aos seus visitantes a possibilidade de vivenciar a história de seu povo, como também, resgatar suas experiências, propõe roteiros ecológicos e culturais oportunizando conhecer o cerrado do Planalto Central, mostrando suas características. Atua nos municípios de Corumbá de Goiás, Pirenópolis, 
Cocalzinho, Águas Lindas, Santo Antônio do Descoberto, Abadiânia e Alexânia, todos fazendo parte do estado de Goiás e do entorno do Distrito Federal.

“O Ecomuseu do Cerrado está localizado na microrregião denominada Planalto Goiano entre os paralelos $15^{\circ} 20^{\prime}$ e $16^{\circ} 20^{\prime}$ de Latitude Sul e os meridianos $48^{\circ} 00^{\prime}$ e $49^{\circ} 20^{\prime}$ de Longitude Oeste. Limita-se ao norte com os municípios de Padre Bernardo, Vila Propício e Goianésia, a oeste com Jaraguá, São Francisco de Goiás e Petrolina de Goiás, ao sul com Anápolis, Silvânia e Luziânia e a leste com o Distrito Federal.

No sentido leste-oeste, a região é cortada pelo Divisor Continental de Águas na qual separam as bacias Amazônica e Platina e inúmeras nascentes que cortam várias cidades e povoados, até chegarem ao oceano. É por esse motivo que a região é caracterizada como "berço das águas”. Também se encontra o Pico dos Pirineus, o ponto mais alto da região com altitude de 1.385 metros acima do nível do mar que fazem juntamente com o relevo existente, a composição de rios, ribeirões, córregos, cachoeiras, corredeiras e balneários formando lindos lugares que significam verdadeiros santuários ecológicos, com inúmera diversidade de espécies da fauna e da flora típicas de cerrado de altitude.

Sendo o bioma cerrado bastante alterado pela atividade econômica agropecuária, há locais que ainda estão intocáveis, que precisam ser preservados, principalmente, por existirem importantes nascentes que abastecem as duas bacias hidrográficas que compõem a região.

O Ecomuseu do Cerrado é uma proposta de trabalho que visa contribuir para a conservação ambiental da bacia do alto rio Corumbá com base no planejamento biorregional voltadas para conservação da natureza, o uso sustentável dos recursos naturais e melhoria da qualidade de vida das populações locais dos sete municípios que o compõem.

Um dos princípios de trabalho do Ecomuseu do Cerrado são projetos relacionados à gestão biorregional como método técnico e científico para planejamento e manejo em escala regional. Este é um tipo de projeto em que é similar aos projetos de ecomuseus de outros países tais como Suíça, Estados Unidos, Canadá e Austrália, que utilizam estratégias de planejamento 
biorregional para harmonizar a conservação da natureza com atividades sócio-econômicas, objetivando a sustentabilidade.

O Ecomuseu do Cerrado é uma iniciativa que teve sua origem em iniciativas das bases de segmentos do movimento social. As primeiras articulações e reuniões ocorreram a partir de 1997 nos municípios que integram a região de Pirenópolis, no estado de Goiás.

Diversos personagens fizeram parte desse início de trabalho, tais como as instituições particulares e públicas como o Instituto Huah do Planalto Central, o Instituto Brasileiro do Meio Ambiente e dos Recursos Naturais Renováveis - IBAMA, Prefeituras Municipais, órgãos estaduais de Goiás e principalmente a participação da população local.

O Ecomuseu do Cerrado tem como objetivo geral, construir por meio da união desses municípios que o constitui, todo o seu território espacial, ações que visem conservação e preservação da natureza, o uso sustentável de seus recursos naturais e a distribuição, de forma justa, das riquezas geradas pela sociedade.

Prevê articular com os segmentos políticos e sociais por meio de um modelo que abrange o desenvolvimento sustentável; a capacitação de todos os segmentos sociais envolvidos no processo da construção; implementação de ações que visem a conservação da biodiversidade e dos ecossistemas; definição de estratégias para a conservação de recursos hídricos, ao longo prazo, e visem permitir acesso à sociedade; propagação de novas tecnologias para a sustentabilidade dos recursos não renováveis em todos os setores sócio-econômicos; fomentação de propostas que possam contribuir para geração de empregos e rendas e coordenação de implantação de ações que promovam o resgate e exercícios de atividades sociais, culturais e folclóricas da região do Ecomuseu do Cerrado.

Os principais pontos abordados para o planejamento do Ecomuseu do Cerrado são: planejamento e gestão participativos; planejamento adaptativo com bases no conhecimento científico e popular; capacitação dos segmentos sociais; criação, manutenção e recuperação de áreas protegidas (áreas núcleos); emprego de metodologias sustentáveis rumo à economia 
sustentável e desenvolvimento de capacidade cooperativa nos planos locais, regionais e internacionais.

Os resultados alcançados desde a implantação do Ecomuseu do Cerrado, foram de grande importância para a população e para os municípios, como por exemplo: a ecologização e articulação das administrações municipais criando secretarias de meio ambiente e conselhos municipais de meio ambiente; articulação e integração das atividades e projetos na perspectiva biorregional; criação do conselho gestor e representação dos municípios; campanhas para criação de reservas particulares do patrimônio natural - RPPN's e estudos de novas áreas protegidas; capacitação dos diversos segmentos com cursos e treinamentos em gestão biorregional, manejo de lixo, manejo do fogo e fauna, administração dos recursos hídricos e educação ambiental; planejamento e implantação de viveiros de mudas para recuperação do ecossistema do cerrado; estudos e iniciativas para o fomento do ecoturismo com roteiros e trilhas ecológicas e planejamento e articulação para criação definitiva do Ecomuseu do Cerrado em Cocalzinho.

Foi feito um levantamento sobre o roteiro turístico do Ecomuseu do Cerrado em junho de 2001, pelo consultor Bismarque Villa Real, em que dados como a história, a localização, aspectos econômicos, atrativos naturais e culturais, áreas protegidas e outros elementos, foram levantados, para verificar quais atrativos turísticos existentes em cada região que compõem o Ecomuseu do Cerrado. É bom ressaltar, que não foi relatado aqui todos os dados apresentados nesse relatório. Segue algumas adaptações apresentadas a partir desse estudo:

\subsection{1- ${ }^{1}$ CARACTERÍSTICAS DA REGIÃO DO ECOMUSEU DO CERRADO}

A riqueza mineral existente na região, descoberta pela expedição precursora do Anhanguera pai em 1680, trouxe no início do século XVIII as bandeiras que viriam a fundar diversos arraiais nos locais onde o ouro era abundante. Daí resultou a antiga Minas de Nossa Senhora

\footnotetext{
${ }^{1}$ REAL, Bismarque Villa. “Ecomuseu do Cerrado”- Relatório para roteiro turístico, junho de 2001.
} 
do Rosário de Meya Ponte, atual Pirenópolis, a Corumbá de Goiás, que conserva o nome Corumbá desde sua fundação e a Fazenda Montes Claros, atual Santo Antônio do Descoberto, esta não constituindo em povoado devido à escassez do ouro, mas tornando-se referência espiritual onde ocorrem romarias em homenagem ao Santo Antônio de Lisboa.

Os outros municípios de Ecomuseu têm história de sua fundação em épocas mais recentes, mas nem por isso com menos importância no contexto da ocupação do Planalto Central. Muitos caminhos cortavam a região, ou vindos de Santa Luzia, atual Luziânia, passando por Santo Antônio do Descoberto, ou vindos da Bahia cruzando o Distrito Federal e o município de Cocalzinho, interceptando-se para seguir Corumbá e Pirenópolis, depois Jaraguá, Goiás e outras localidades mais a Oeste do Brasil.

Talvez os bandeirantes não tivessem consciência, num primeiro momento, que justamente nesta região eles ultrapassavam a Linha de Tordesilhas, ocupando o território que desde 1494 pertencia à Espanha. A nova delimitação do território brasileiro só foi definida pelo Tratado de Madri em 1750.

Pois esta histórica linha imaginária mas também real medida pela Longitude Oeste 48³5’25”, cruza os atuais municípios de Cocalzinho, no km 47 da BR 070, Corumbá na confluência do córrego Falcão com o Rio Areias, Alexânia nas imediações da ponte do Rio Corumbá na BR 060 e, coisas do destino, parte ao meio a Praça do Troca no povoado de Olhos d’Água. Corta, ainda, o município de Abadiânia em sua porção Leste.

Ao longo destes quase 300 anos, muitos viajantes, políticos, naturalistas e cientistas percorreram os antigos caminhos bandeirantes e deixaram suas impressões através de textos e desenhos, alguns registrando a natureza e os costumes goianos. Entre os anos 1819 e 1923 passaram o naturalista Auguste de Saint'Hilaire, o geógrafo brigadeiro Cunha Matos e o médico, mineralogista e botânico Dr. Johann Emanuel Pohl. Em 1827, o botânico William John Burchell deixou seu registro em extraordinárias aquarelas e aguadas. 
Em 1889, Oscar Leal, considerado o pioneiro das reportagens sobre o Centro-Oeste, tendo viajado pela região durante quase dois anos, conviveu por bom tempo com o povo pirenopolino. Deixou registrado em seu livro Viagens às Terras Goyanas diversos fatos pitorescos sobre a cidade e seus habitantes, e descreve com maestria uma expedição ao Pico dos Pireneus.

Em 1892, quando da realização dos estudos para a transferência da Capital Brasileira para o Planalto Central, uma comitiva da Comissão Cruls, comandada pelo Dr. Ernesto Ule, visitou a região fazendo levantamento botânico e finalmente aferindo a altitude do Pico dos Pireneus: 1.370 metros acima do nível do mar.

A riqueza natural e eco-histórica desta região, se constitui portanto, num imenso patrimônio para o Ecomuseu do Cerrado.

Não é de muito tempo para cá que os atrativos naturais da região vêm sendo visitados por turistas. O Salto do Corumbá já era visitado, mas Pirenópolis foi pioneiro em adotar uma postura de tornar seus atrativos rentáveis, iniciado pelo bem sucedido empreendimento Santuário de Vida Silvestre Fazenda Vagafogo.

De 1680 aos dias atuais muitos outros empreendimentos surgiram, estendendo-se aos municípios vizinhos de Corumbá e Cocalzinho, transformando assim inúmeros atrativos em receptivos turísticos.

\subsubsection{2-RELATÓRIO POR MUNICÍPIO}

\section{ABADIÂNIA}

\section{Breve Histórico}

Abadiânia teve sua origem no povoado que se formou em torno de uma capela dedicada a Nossa Senhora d'Abadia. Ali, durante a década de 1910, anualmente Dona Emerenciana 
promovia e custeava uma reza em louvor à Santa. Por influência da devoção de Dona Emerenciana, João José da Maia, Manoel Gomes Ferreira, Joaquim de Souza Cordeiro e outros, doaram ao patrimônio de Nossa Senhora d'Abadia uma área para formação do povoado, então denominado Posse d'Abadia.

Em 31 de dezembro de 1943, o povoado tornou-se distrito de Corumbá de Goiás, com a denominação de Abadiânia, tendo conquistada sua emancipação política em 1953. Em 1963, a sede foi transferida para as margens da BR-060.

\section{Localização e Acessos}

O município de Abadiânia está localizado na microrregião denominada Planalto Goiano. Faz limite ao Norte com o município de Corumbá de Goiás, a Oeste com Pirenópolis e Anápolis, ao Sul com Silvânia e a Leste com Alexânia. A cidade de Abadiânia está localizada às margens da BR 060, a uma distância de 100 km de Brasília e a 90 km de Goiânia. A sede do município, tem como coordenadas geográficas 16¹1’47” de Latitude Sul e 4842’22” de Longitude Oeste. O município tem uma área territorial de 1.044 km².

\section{Relevo e Hidrografia}

O relevo do município é acidentado, indo até os contrafortes da Serra dos Pireneus a Oeste. A altitude na sede municipal é de 1.052 metros.

Tem os rios Corumbá e das Antas fazendo limites com Alexânia e Silvânia respectivamente, e são cortados pelo Rio Capivari que tem suas nascentes na Serra dos Pireneus. Banhados por diversos afluentes dos rios Capivari e das Antas, em cuja confluência, o município será atingido pela barragem Corumbá IV. As águas que percorrem o território de Abadiânia são todas da bacia do Prata.

\section{Aspectos Econômicos}


A atividade econômica predominante se concentra na pecuária, principalmente a criação de bovinos e suínos. A agricultura vem se desenvolvendo produzindo milho, feijão, arroz, soja, mandioca, cana de açúcar, tomate, banana e café. Na indústria destacam-se as olarias e utensílios de cerâmica em geral. Há ainda uma atividade expressiva na extração de areia dos leitos dos rios Corumbá, Capivari e das Antas. A cidade apresenta, também, um comércio bastante diversificado e serviços em geral.

\section{CONDIÇÕES GERAIS PARA O TURISMO}

A infra-estrutura turística de Abadiânia atende, fundamentalmente, às pessoas que para ali de deslocam em busca de um tratamento espiritual. A Casa de Dom Inácio de Loyola transformou-se em um pólo de atração de verdadeiras multidões que para aí acorrem, vindas de todas as regiões do Brasil e até mesmo do exterior para curar os mais diversos tipos de patologias.

Pelo fato da cidade estar localizada às margens da rodovia BR 060, os serviços que ela oferece, atendem também viajantes que permanecem por pouco tempo.

\section{Atrativos Históricos e Culturais}

Posse d'Abadia foi o povoado que deu origem ao município, a 18 km de Abadiânia por estrada de terra e a $08 \mathrm{~km}$ de Planalmira por asfalto. Mantém sua arquitetura antiga na maioria de suas 194 casas, que abrigam aproximadamente 600 pessoas.

Artesanato - O artesanato em Abadiânia é bastante diversificado e de boa qualidade, produzindo cerâmicas, como vasos, fruteiras, potes de água, esculturas e utensílios de cozinha em geral; bordados, tapeçarias, tecidos e crochês; esculturas em pedra sabão; pinturas sobre tela; miniaturas em madeira e comidas típicas.

\section{CALENDÁRIO DE EVENTOS}


*Festa de São Sebastião - Comemorado no dia 20 de janeiro e no domingo que antecede, com novena, procissão, músicas sacras e populares, leilão beneficente, bingo e show pirotécnico. *Carnaval de Rua - Todos os dias, com forró e trio elétrico. Baile de carnaval no Clube Primavera.

*Festas Juninas - Entre os dias 20 e 29 de junho, com desfile de carroças nas ruas da cidade, festejos nas escolas com barracas, comidas e bebidas. Também com apresentação de danças de quadrilhas e catiras.

*Festa de São Pedro - Comemorado no dia 29 de junho com novena e procissão, também com bingo beneficente, quermesse, apresentação de músicas e queima da fogueira.

*Nossa Senhora de Abadia - Padroeira da cidade comemorado no dia 15 de agosto. A festa é realizada em Posse d'Abadia (Abadiânia Velha), onde foi encontrada a imagem de Nossa Senhora d'Abadia, origem do nome da atual cidade. Há festividades durante todo o dia com quermesse, novena, procissão, leilão beneficente, apresentação de músicas e show pirotécnico. *Dia da Árvore - No dia 21 de setembro. É realizada caminhada ecológica e plantações de mudas de árvores, promovida pelas escolas.

*Festa de São Miguel Arcanjo - No dia 29 de setembro e no domingo que antecede. Comemorado com novena, procissão, músicas sacras e populares, leilão beneficente, bingo e show pirotécnico.

*Semana de Comemoração do Aniversário da Cidade com exposição Municipal Artesanal. Nos dias 12 a 20 de outubro.

*Festa do Peão - Com rodeio, exposição, shows de músicas sertanejas, danças, baile, desfiles e eleição da “Garota Country”.

*Natal com as Crianças - Festejos realizados durante a semana do Natal no Ginásio de Esportes com distribuição de brinquedos e lanches para as crianças, com brincadeiras e a participação do Papai Noel.

\section{ÁGUAS LINDAS DE GOIÁS}

\section{Breve Histórico}


Águas Lindas de Goiás, antes conhecida como Parque da Barragem, pertencia ao Município de Santo Antônio do Descoberto. Segundo moradores pioneiros, a origem deste nome deve-se a uma homenagem à nascente “Águas Lindas” existente nas proximidades do Clube Recreativo Águas Lindas. No Parque da Barragem, por volta de 1985 havia apenas o cerrado com algumas poucas fazendas e chácaras.

A existência da rodovia BR-070, corredor de saída do Distrito Federal, propiciou o afluxo de muitas famílias vindas de Brasília e outras cidades próximas que foram se aglutinando às suas margens, gerando posteriormente a explosão demográfica que temos conhecimento.

A emancipação se deu após um abaixo-assinado conduzido por lideranças locais, culminando com o Plebiscito no Parque da Barragem, realizado em 12 de outubro de 1995, com 92\% da população apoiando a emancipação.

\section{Localização e Acessos}

O município de Águas Lindas está localizado na microrregião denominada Planalto Goiano. Faz limite a Noroeste com o município de Cocalzinho de Goiás através do Rio dos Macacos, ao Sul com Santo Antônio do Descoberto e a Leste com o Distrito Federal através do Rio Descoberto e da barragem do mesmo nome.

A cidade está localizada às margens da BR 070, a uma distância de 50 km de Brasília e a 230 km de Goiânia. A sede do município tem como coordenadas geográficas 1545’15” de Latitude Sul e $48^{\circ} 15^{\prime} 44^{\prime}$ ' de Longitude Oeste.

O acesso a Águas Lindas, além da BR 070, pode ser pela estrada GO 547, estrada de terra que liga a Santo Antônio do Descoberto passando pela Cidade Eclética. O município tem uma área territorial de $191 \mathrm{~km}^{2}$. É o menor município do Ecomuseu do Cerrado.

\section{Relevo e Hidrografia}


O relevo do município se caracteriza em grande parte por áreas planas, com depressões próximas ao Rio Descoberto e com altitudes máximas ultrapassando os 1.100 metros. A altitude da sede municipal é 1.080 metros.

As águas que percorrem seu território vão todas para a bacia do Prata pelos rios Macacos e Descoberto, afluentes do Rio Corumbá.

\section{Aspectos Econômicos}

Águas Lindas vem procurando atrair mais empreendimentos, que se somam aproximadamente 5.000 empresas formais e informais, com atividades nas áreas de cerâmica, artefatos de cimento, brinquedos, móveis e confecções. O comércio predominante é de material de construção.

Na área industrial, há empreendimentos predominantes em móveis comerciais e produtos de ferro que são exportados para todo o país. Também é relevante a indústria de reciclagem de ferro.

$\mathrm{Na}$ agricultura, a cidade conta com pequenos produtores de hortifrutigranjeiros, onde se destaca a produção de hortaliças que são vendidas principalmente para o Distrito Federal.

\section{CONDIÇÕES GERAIS PARA O TURISMO}

Os serviços existentes em Águas Lindas atendem fundamentalmente à população local ou a visitantes com permanência rápida. Alguns empreendimentos que vêm apresentando boa qualidade de serviços são postos de combustíveis, instalados ao longo da BR 070, onde oferecem lojas de conveniência e outros serviços.

\section{Atrativos Naturais}


Os atrativos abertos ao público em Águas Lindas, são poucos, contando com:

*Balneário Barragem Santo Antônio do Descoberto - Freqüentado principalmente pelo público de Águas Lindas, pelo público do Distrito Federal e das cidades mais próximas à barragem.

*Clube Recreativo Águas Lindas - Foi muito freqüentado outrora e hoje sofre com os impactos causados pelos inúmeros loteamentos implantados ao seu redor, alguns deles responsáveis pela significativa queda de vazão da fonte de água ali existente.

*Pesque-Pague - Contém dois tanques, uma piscina, bar e restaurante. Localizado no bairro Mansões Village, próximo à Escola MED-Guão.

\section{CALENDÁRIO DE EVENTOS}

*Carnaval de rua - No Jardim Brasília, é animado com Trio Elétrico diariamente.

*Festas Juninas - Nas escolas, contendo barraquinhas, eleição da Rainha Caipira, danças de quadrilhas, jogos, comidas e bebidas típicas.

*Rodeio - No mês de julho com duração de quatro dias, tem apresentação de música sertaneja, concursos, danças, quiosques, parque de diversões, desfile e concurso da “Garota Rodeio”.

*Feira de Exposições do Município de Águas Lindas de Goiás - FEMALGO - Realizada na primeira semana de setembro, com exposições, serviços e trabalhos promovidos por diversas secretarias.

*Natal - Comemorado com o bolo da Dona Celina. É um enorme bolo comunitário e servido à população na véspera do Natal. Preparado e confeitado por lideranças comunitárias com o apoio da Prefeitura. Também é distribuído brinquedos e refrigerantes para as crianças com animação de Trio Elétrico e muitas brincadeiras. Este evento se realiza pela manhã, no Galpão da BR-070 próximo ao Jardim Brasília.

De todos os municípios que compõem o Ecomuseu do Cerrado, Águas Lindas é o que menos tem a oferecer de atrativos e serviços aos turistas. Mas nem por isso, deixa de ter suas riquezas naturais, como trilhas e grutas ainda desconhecidas para o público.

Há projetos para transformar a beira da barragem num Parque para o ecoturismo, equipado com hotel-fazenda, pesque-pague, trilhas e viveiros numa área de 4,5 alqueires. Outra 
possibilidade de atrativo turístico, fica próximo ao Rio dos Macacos, que faz divisa com Cocalzinho.

\section{ALEXÂNIA}

\section{Breve Histórico}

Alexânia teve suas raízes no povoado de Olhos d’Água. Em fins do século XIX, uma senhora negra, chamada Maria Sebastiana Marques, mãe de família, temerosa pelos boatos veiculados por um viajante de que a escravidão não fora abolida, fez um voto a Santo Antônio, pedindo a graça da confirmação da liberdade que ouvira dizer, garantida pela Lei Áurea. Neste caso construiria uma capela ao santo. Confirmada a boa nova, Dona Maria pediu a dois fazendeiros da região, Sr. Geminiano Ferreira de Queiroz e Sr. Juvenal Fernandes Parente, no que foi atendida, as terras onde depois ergueria a capela de Santo Antônio dos Olhos d’Água, com seu marido e seus filhos.

Em volta da Igreja nasceu o povoado de Olhos d’Água, na época distrito do município de Corumbá de Goiás. Depois veio a emancipação política de Olhos d’Água, em 30 de novembro de 1959 e, na gestão do prefeito Alex Abdalla, quando foi pavimentada a rodovia BR-060, a sede foi transferida em 1961, para as margens da rodovia, recebendo assim o novo nome de Alexânia.

Uma curiosidade em Olhos d’Água é justamente na Praça do Troca, em frente a Igreja de Santo Antônio, cruza a histórica Linha de Tordesilhas, que delimitou o território brasileiro a Oeste, até o ano de 1750.

Alexânia é uma das poucas cidades que, a exemplo de Brasília, foi planejada, possuindo uma planta moderna e rica em áreas destinadas às construções públicas, parques, praças e residências. 


\section{Localização e Acessos}

O município tem uma área territorial de $848 \mathrm{~km}^{2}$. Está localizado na microrregião denominada Planalto Goiano. Faz limite ao Norte e a Oeste com o município de Corumbá de Goiás, ao Sudeste com Abadiânia, ao Sul com Silvânia e a Leste com Santo Antônio do Descoberto. Em sua extensa área inclui os distritos de Olhos d’Água, Alvorada, Serra do Ouro, Morada do Sol e Estiva.

A cidade está localizada às margens da BR 060, a uma distância de 70 km de Brasília e a 120 km de Goiânia. A sede do município tem como coordenadas geográficas $16^{\circ} 05^{\prime 2} 27^{\prime \prime}$ de Latitude Sul e 48²9’49” de Longitude Oeste, e está a uma altitude de 1.096 metros.

O principal acesso a Alexânia é a própria BR 060, ligando-se também a Corumbá, pela rodovia GO 139 seguida pela GO 225, não pavimentadas.

\section{Relevo e Hidrografia}

O seu relevo é bastante acidentado com morros que ultrapassam a altitude de 1.100 metros.

As águas que percorrem o território de Alexânia são todas da bacia do Prata, sendo os rios mais importantes o Corumbá, Macacos, Areias e das Antas. Os ribeirões Sapezal, Galinha e do Ouro, fazem parte da hidrografia do munícipio. No sul, localizará a barragem Corumbá IV, na confluência dos rios Areias e Corumbá.

Entre suas riquezas minerais que mais se destacam são: columbita, mica, ferro, calcário, amianto e areia lavada.

\section{Aspectos Econômicos}


A atividade econômica predominante é o comércio, sobre tudo o de secos e molhados, com $72 \%$ da renda; seguida pela indústria, com destaque na extração de areia, fabricação de móveis e cerâmica, fornecimento de cereais com $18 \%$ da renda; setor de serviços, representando cerca de $9 \%$ da renda e uma incipiente pecuária com 1\% da renda do município. A pecuária ocupa quase $40 \%$ de todas as terras, a agricultura menos de $10 \%$ com destaque para a produção de milho e de banana, que contam inclusive com a industrialização local. O restante da produção é bastante diversificado, caracterizando-se por uma agricultura de subsistência de baixa produtividade e com custos elevados para uma eventual comercialização.

A indústria moveleira é muito dinâmica e variada, pode ser considerada uma das vocações da cidade que emprega uma boa quantidade de mão-de-obra aumentando a especialização do pessoal do município. Produz móveis rústicos, finos e populares, em madeira, couro, bambu, vime e junco.

Há também uma grande quantidade de atividades ligadas ao artesanato, produzindo materiais em cerâmica, pedra, resina, couro, metal, tecelagem, cestaria, brinquedos e entalhes em madeira. A abundância de argila de boa qualidade no município, permite um desenvolvimento ainda maior nas atividades que utiliza esta matéria-prima.

\section{CONDIÇÕES GERAIS PARA O TURISMO}

O município conta com diversos empreendimentos na zona rural, freqüentados principalmente pelo público proveniente de Brasília. São as fazendas antigas transformadas em Hotel Fazenda, ou novos empreendimentos.

\section{CALENDÁRIO DE EVENTOS}

*Festa de São Sebastião- Romaria em homenagem a São Sebastião. Festa local que atrai pessoas da redondeza, data prevista para a segunda quinzena de janeiro. Ocorre em Alexânia e Olhos d’Água. 
*Festa do Divino Espírito Santo - Com apresentação de folia, catira, comidas típicas e rezas. É uma festa regional, comemorada em no mês de maio.

*Festas juninas: Comemorando os dias de Santo Antônio, São João e São Pedro.

*Festa do Imaculado Coração de Maria, padroeira do município - Com novena que encerra no dia 15 de setembro, o dia da Padroeira.

*Aniversário da Cidade - No dia 14 de novembro, comemora-se com gincanas, jogos escolares e outros eventos.

*Feira de Trocas - Em Olhos d’Água, foi criada a feira em 1974 que propiciou um grande movimento de resgate cultural, promovendo um surto de desenvolvimento sócio-econômico em toda a região. A Feira de Trocas influenciou na economia e na preservação do meio ambiente através do resgate dos fazeres culturais da população. É realizada na pracinha, sempre aos domingos, nos meses de junho e dezembro de cada ano. Troca-se artesanato por produtos industrializados e já está sendo visitadas também por turistas estrangeiros.

*Casa da Memória e do Fazer de Olhos d’Água - Conta com uma coleção de peças artesanais, fotografias e documentos que registram a tradição e a origem de Olhos d’Água. Nesse local freqüentemente se realizam manifestações da cultura popular como catiras, também há exposições, encenações e reuniões de artistas da região.

Alexânia é um município muito bem servido por rios e córregos, como também por bonitas paisagens. A sua proximidade com Brasília fez com que muitas pessoas, em busca de opção de vida mais próxima à natureza, adquirissem imóveis rurais. A partir dessa aquisição, alguns proprietários foram transformando seus sítios em atrativos, dos quais já sobrevivem com a renda gerada pelo seu empreendimento.

Percebe-se, então, que a vocação de Alexânia é o desenvolvimento do turismo no meio rural, tornando-se uma opção à população de Brasília.

\section{COCALZINHO DE GOIÁS}

\section{Breve Histórico}


Cocalzinho surgiu a partir da instalação de uma fábrica de cimento da Cia. de Cimento Portland Itaú, da família paulistana Ermírio de Moraes. Em terras da família Curado Fleury, mais precisamente, Fazenda Taquaral, em 1960, a empresa iniciou suas atividades. Em torno dela, surgiu a Cidade dos Pirineus, um loteamento ligado ao município de Corumbá de Goiás. Foi o projeto da Cidade dos Pirineus que originou a cidade de Cocalzinho. Obedeceu modernas normas de urbanização com ruas e avenidas planas. Foi assentada em terras doadas por Silvio do Rosário Curado Fleury, considerado um dos benfeitores do município.

A emancipação política de Cocalzinho ocorreu em 3 de julho de 1990. Em 1992 houve a posse do primeiro prefeito na Câmara dos Vereadores.

\section{Localização e Acessos}

O município tem uma área territorial de $1.788 \mathrm{~km}^{2}$. Está localizado na microrregião denominada Planalto Goiano. Faz limite ao Norte com os municípios de Padre Bernardo e Vila Propício, a Oeste com Pirenópolis, ao Sul com Corumbá de Goiás e a Leste com Santo Antônio do Descoberto e Águas Lindas de Goiás.

A cidade está às margens da BR 414, quase na confluência com a BR 070. Sua distância de Brasília é de 100 Km pela BR 070 e a 120 km de Goiânia pela BR 153, que continua pela BR 414, via Corumbá de Goiás.

A sede do município tem como coordenadas geográficas $15^{\circ} 47^{\prime} 22$ ” de Latitude Sul e 4846’28” de Longitude Oeste.

\section{Relevo e Hidrografia}

O relevo é bastante acidentado e muito curioso, pois o município é cortado de Leste a Oeste pelo grande divisor de águas que separa as bacias Amazônica e Prata, justamente por onde passa a BR 070 que liga a Brasília. 
As águas que percorrem o território criam uma infinidade de cachoeiras e corredeiras de beleza ímpar, própria à exploração turística. Os principais rios que cruzam o município são: Pela Bacia Amazônica: o Rio Verde, com seus afluentes Oliveira Costa, Jacaré, Piqui e Taquaral. Pela Bacia do Prata: os rios Corumbá e Areias.

A altitude varia de 800 a 1.200 metros e a sede do município tem como cota 1.152 metros.

Tem como recursos minerais o Calcário, Argila, Areia e Pedras Ornamentais.

\section{Aspectos Econômicos}

Estão localizadas no município, grandes empresas pecuaristas voltadas principalmente para o corte, com aprimoramento de raças e maior nível técnico no manejo do gado. Grande parte dessas fazendas pertence a empresários residentes em Brasília, sendo comum a atuação de empresas de grande porte como a Skol e a Combrasil.

\section{Áreas Protegidas}

Cocalzinho tem como áreas protegidas o Parque Estadual dos Pireneus e a APA Pireneus, que abrangem também os municípios de Pirenópolis e Corumbá de Goiás.

\section{CONDIÇÕES GERAIS PARA O TURISMO}

O município de Cocalzinho é privilegiado sob o ponto de vista dos atrativos naturais nele existente. Tem um relevo acidentado com diversas escarpas, é muito bem servido de águas e, pelo fato de ser uma região calcária, existe ocorrência de grutas em seu território.

O turismo, porém, é incipiente, estando ainda ofuscado pelos municípios vizinhos de Pirenópolis e Corumbá que oferecem atrativos e serviços de qualidade. 


\section{CALENDÁRIO DE EVENTOS}

*Encontro das Águas - Comemorado no dia 22 de março.

*Festa de Folias - A Festa do Divino Espírito Santo com a Folia, ocorre em maio em Edilândia.

*Festa de Santo Antônio - Iniciada há 33 anos logo após o surgimento do vilarejo. A festa em louvor a Santo Antônio, padroeiro da cidade, era organizada pelos católicos, anualmente, em torno do dia 12 de junho. Mas recentemente, foi adiada para a primeira semana de julho, para coincidir com o período das férias escolares. Além da religiosidade que a envolve, são promovidos shows artísticos, eventos esportivos e são montadas barracas típicas vendendo diversos gêneros.

*Rodeio Show - Ocorre nas primeiras semanas de junho desde 1997. O evento atrai grande público, tornando-se uma tradição em Cocalzinho.

*Corrida de Motocross - Acontece em setembro com a Associação Papa-Légua Trail.

O município de Cocalzinho é reconhecido pela EMBRATUR como potencial turístico, o que tem incentivado nos últimos anos, um trabalho de implantação da infra-estrutura turística, com projetos de reflorestamento e preservação de bacias fluviais, em especial a edificação do Centro de Proteção Ambiental do Rio Corumbá - CEPARC, onde serão instalados a EMATER, o Ecomuseu do Cerrado e a Guarda Florestal Municipal, dotado de viveiro de mudas para reflorestamento.

Há no município alguns empreendimentos, principalmente às margens dos Rios Areias e Corumbá, cujos proprietários vêm explorando a atividade campista. No geral a infra-estrutura é insuficiente para os empreendimentos. Alguns proprietários não têm consciência da necessidade de um planejamento para a sua propriedade, e constróem conforme sua visão, às vezes causando danos irreparáveis na natureza.

Existem muitos atrativos naturais, como cachoeiras, balneários, trilhas, mirantes, escarpas que chegam a 70 metros de altura que possibilitam, além do ecoturismo, esportes radicais. Porém, estes locais não estão abertos ao público, tendo acesso a eles, somente pessoas das relações 
pessoais dos proprietários.

A Gruta dos Ecos, com 1.500 metros de extensão, onde se encontra o maior lago subterrâneo da América do Sul, é um verdadeiro monumento da natureza. Atualmente encontra-se interditado pelo IBAMA para fins turísticos. Segundo a Portaria IBAMA $n^{\circ} 14$, de 23 de fevereiro de 2001, há necessidade da realização do Plano de Manejo da caverna para que ela possa voltar a ser visitada.

De Leste a Oeste o município é cortado pelo grande Divisor de Águas, onde abriram muitos caminhos bandeirantes no século XVIII que, ainda hoje, é possível identificá-los. Muros e casas antigas testemunham a ocupação da região naquela época.

O Pico dos Pireneus em conjunto com o Morro do Cabeludo é patrimônio comum com o município de Pirenópolis, estando mais próximo de Cocalzinho, onde o acesso é fácil.

A BR 070, por onde passa um grande fluxo de pessoas cujo destino é Pirenópolis ou Corumbá, é um local que tem potencial para o desenvolvimento do turismo, como também a rodovia 414, que corta o município de Sul a Norte.

\section{CORUMBÀ DE GOIÁS}

\section{Breve Histórico}

Segundo Ramir Curado, o surgimento da cidade de Corumbá de Goiás aconteceu no ano de 1729 devido à descoberta de ouro no local onde as águas do Ribeirão Bagagem encontram-se com as do Rio Corumbá, no chamado Poço Rico, atual Poço da Brandina, onde os bandeirantes teriam organizado um garimpo. 
Corumbá é uma das cidades mais antigas de Goiás, e conserva este nome desde a data de sua fundação. Segundo anotações antigas, provém do nome do rio que banha a sede do Município. Do tupi: Curu (branco); Mbá (cascalho). Portanto, cascalho branco.

Seus primeiros habitantes eram de origem paulista e portuguesa, oriundos das bandeiras de Bartolomeu Bueno da Silva, que construíram suas moradias às margens do Rio Corumbá por conta da abundância de veios auríferos ali existentes.

A sede do município foi considerada à categoria de vila em 1849. Perdeu essa categoria em 1863 voltando a pertencer à Meia Ponte, atual Pirenópolis, e foi restaurada como vila novamente em 1876. Foi considerada como cidade em 9 de julho de 1902 por efeito da Lei Estadual n 237, projeto de autoria do deputado Antônio Félix Curado.

\section{Localização e Acessos}

O município tem uma área territorial de $1.062 \mathrm{~km}^{2}$. Corumbá de Goiás está localizado na microrregião denominada Planalto Goiano. Faz limite ao Norte com o município de Cocalzinho, a Oeste com Pirenópolis, ao Sul com Abadiânia e a Leste com Alexânia e Santo Antônio do Descoberto. A cidade de Corumbá está a uma distância de 130 km de Brasília, ligada pela BR 070 até Cocalzinho, seguida pela BR 414, e 100 km de Goiânia, ligada pela mesma BR 414 até Anápolis, seguida pela BR 153 até a capital do Estado, todas asfaltadas, em bom estado de conservação.

Outro acesso importante, liga Corumbá a Pirenópolis, numa distância de 19 km, pela GO 225. Esta mesma estrada vem desde Santo Antônio do Descoberto sem pavimentação, construída em boa parte em antigas estradas bandeirantes do século XVIII.

A sede do município tem como coordenadas geográficas $15^{\circ} 55^{\prime 2} 25^{\prime \prime}$ de Latitude Sul e 4848’31” de Longitude Oeste. 


\section{Relevo e Hidrografia}

O município está separado de Pirenópolis pela Serra dos Pireneus, serra esta que contém o pico mais alto do grande divisor das bacias Amazônica e do Prata. As águas que banham o município vão todas para a Bacia do Prata, formando os rios Corumbá e Areias que servem, em grandes extensões, como divisa dos municípios de Abadiânia, Cocalzinho e Santo Antônio do Descoberto, e o Rio do Ouro, afluente do Corumbá, separa o município de Alexânia.

Por se tratar de uma região com relevo bastante acidentado, com altitude média de 962 metros, chegando a ultrapassar 1200 metros em alguns pontos, tem um sistema de drenagem abundante. Seus rios e córregos formam inúmeras cachoeiras e quedas d’água que se espalham por todo o município, algumas chegando a atingir 60 metros de altura.

\section{Aspectos Econômicos}

A economia do município está baseada na pecuária e na agricultura. Na pecuária, o rebanho bovino é maior e na agricultura produz-se milho, arroz e feijão, além da mandioca e da canade-açúcar, como também, hortaliças e frutas.

O comércio é bastante variável, porém sofre uma enorme concorrência com Anápolis e outros grandes centros comerciais, isso se deve a curta distância que separa o município desses centros. Na indústria, há pequenas olarias, que em quase totalidade, são empresas familiares. Além dessas, há duas pequenas indústrias de laticínios.

\section{Áreas Protegidas}

Corumbá tem como áreas protegidas uma pequena parte do Parque Estadual dos Pireneus e a APA Pireneus, que abrangem também os municípios de Pirenópolis e Cocalzinho de Goiás. 


\section{CONDIÇÕES GERAIS PARA O TURISMO}

Corumbá é uma cidade antiga, com um centro histórico significativo, onde casarões seculares vêm passando por transformações para atender a um turismo crescente, havendo pelo menos, 04 prédios antigos adaptados para pousadas e restaurantes. Além desses, novos empreendimentos vêm surgindo nos últimos anos, demonstrando a vocação do município para o turismo e o interesse da população para tal.

\section{Atrativos naturais}

Os atrativos naturais até bem pouco tempo resumia-se ao Salto de Corumbá, hoje somam-se mais alguns, basicamente ao longo do Rio Corumbá caracterizando-se fundamentalmente por locais apropriados para banhos. Em sua maioria, são caracterizados como locais planos disponibilizados para campings, como também estão sendo implantados estruturas para chalés.

\section{Atrativos Históricos e Culturais}

*Igreja de Nossa Senhora da Penha de França construída entre 1774 e 1880, com belas pinturas e imagens, entre elas a imagem de Nossa Senhora da Penha, padroeira da cidade, datada de 1775.

*Ponte sobre o Rio Corumbá, construída sob direção de Antônio Féliz Curado entre 1897 e 1901, com 110 metros de comprimento toda em madeira.

*Sobrado de Áurea Fleury, construída pelo comendador João José de Campos Curado Fleury, entre 1828 e 1840, primeiro estabelecimento comercial que funcionou também, como sede regional da Guarda Nacional e Juizado de Órfãos.

*Casa da Associação Aldeia da Paz, construída em 1868 pelo Padre Manoel Inocêncio da Costa Campos, primeiro Vigário de Corumbá, para o primeiro hospital e a primeira escola normal da cidade.

*Corporação Musical 13 de Maio, fundada em 13 de maio de 1890, casa de consagrados compositores, com um acervo atual de mais de 700 peças musicais. 
*Biblioteca Municipal Monsenhor Chiquinho, fundada em 1897 pelo Monsenhor Francisco Xavier da Silva, detentora, ainda hoje, de verdadeiras raridades bibliográficas.

É importante salientar, também, que sob o ponto de vista da ocupação da região no século XVIII, foram abertos caminhos e estradas que cruzavam o município, principalmente a que liga Santo Antônio do Descoberto a Corumbá, na qual foi implantada, em grande extensão, a rodovia GO 225.

Pelos relatos de bandeirantes e naturalistas que por aí passaram nos séculos XVIII e XIX, é possível identificar diversos acidentes geográficos por eles citados e certamente seriam encontrados muitos vestígios que pudessem testemunhar esta ocupação, sendo um bom atrativo para o desenvolvimento do ecoturismo.

\section{CALENDÁRIO DE EVENTOS}

*Festa de São Sebastião - Comemorada com novena e leilões, de 13 a 20 de janeiro.

*Semana Santa - Solenidades tradicionais, tais como as procissões do Encontro, Senhor dos Mortos e os cânticos do Perdão, Sete Palavras e Verônica.

*Festa do Divino Espírito Santo, Santo Elesbão e Santa Efigênia em maio ou junho.

*Festas juninas.

*Aniversário da cidade - Comemorado com importantes manifestações artísticas culturais e esportivas.

*Festa de Nossa Senhora da Penha - Festejada com muitas barraquinhas e ranchos de danças em 30 de agosto a 8 de setembro.

*Cavalhadas - Tradicionalmente representando a luta entre Mouros e Cristãos na Idade Média. Representada em Corumbá de Goiás desde 1856.

*Festa de Natal - Com presépios e as folias de Santo Reis em dezembro e janeiro.

O fato de Corumbá possuir abundância de recursos naturais, com muitos rios cortando seu território, um relevo variado, exuberantes formações rochosas e vegetação, fazem dele um 
município de grande potencial turístico. Porém, sua população desconhece a maioria dos atrativos e não há um centro de informações para atender visitantes.

Os atrativos naturais quase todos situados ao longo do Rio Corumbá a montante da cidade, atendem a uma população próxima a 20.000 pessoas em dias de maior movimento. É de se supor que as águas que chegam à cidade, carregam grande quantidade de dejetos gerados nesses empreendimentos.

Nesse caso, deve-se ter levantamentos e estudos para a capacidade de suporte nos locais de visitação, evitando assim, prejuízos que o turismo de massa possa gerar, no qual impacta o ambiente e conseqüentemente a população sente os malefícios.

\section{PIRENÓPOLIS}

\section{Breve Histórico}

Pirenópolis surgiu no início do século XVIII, a partir de um pequeno arraial minerador às margens do Rio das Almas. Incrustada aos pés da Serra dos Pireneus, constitui-se hoje num dos mais ricos acervos patrimoniais do Centro-Oeste, tendo sido tombada pelo Instituto de Patrimônio Histórico e Artístico Nacional - IPHAN, em 1988. Foi um dos primeiros povoamentos do Planalto Central que, como ocorreu com outros povoamentos da época, teve seu desenvolvimento até fins do século XVIII calcado na mineração.

O fato de Pirenópolis situar-se num local de junção das principais estradas da província no século XVIII, propiciou que diversos viajantes a visitassem desde aquela época, alguns deixando curiosos registros sobre a natureza e os costumes goianos.

Entre os anos 1819 e 1823, passaram Auguste de Saint’Hilaire, o geógrafo brigadeiro Cunha Matos e o Dr. Johann Emanuel Pohl. Posteriormente, outros viajantes visitaram Pirenópolis e seus arredores. Em 1889, Oscar Leal, considerado o pioneiro das reportagens sobre o Centro-

Oeste, tendo viajado pela região durante quase dois anos, conviveu por bom tempo com o 
povo pirenopolino. Em 1892, quando da realização dos estudos para a transferência da Capital Brasileira para o Planalto Central, uma comitiva da Missão Cruls, comandada pelo Dr. Ernesto Ule, visitou a região fazendo levantamento botânico e finalmente aferindo a altitude do Pico dos Pireneus que é de 1.385 metros acima do nível do mar.

A cidade viveu momentos de dinamismo e momentos de estagnação. O período entre 1750 e 1800 foi marcado pela decadência da mineração. A partir de 1800, a economia foi reativada com base em culturas diversificadas, principalmente a de algodão, fortalecendo, também, sua função de entreposto de âmbito regional. A estrutura urbana quase não se alterou, tendo ocorrido porém, uma renovação arquitetônica em seus prédios.

Com a construção de novas estradas e a conseqüente alteração das antigas rotas comerciais, na segunda metade do século XIX, o comércio de Meia Ponte perdeu importância no contexto regional e viu-se novamente na estagnação. Esse isolamento só veio romper-se a partir de 1970, principalmente pela influência da nova capital do país instalada a apenas $150 \mathrm{~km}$ de distância. A partir desse momento a cidade expandiu-se com relativa rapidez, sendo grande o número de pessoas que, a partir de Goiânia e Brasília principalmente, adquiriram imóveis, os restauraram e transformaram-nos em casas de finais de semana.

Muitas foram também, as pessoas que optaram por instalarem-se no município a partir da década de 70, principalmente em comunidades hippies. Deve-se a elas o desenvolvimento do artesanato em prata, cujo trabalho é reconhecido também fora dos limites de Pirenópolis.

Cabe ressaltar a condição de Pirenópolis como "Berço da Imprensa Goiana”, pois aí foi impresso o primeiro jornal de Goiás, “A Matutina Meiapontense”, que circulou de 1830 a 1834. É, também, nesta cidade, que desde 1819 ocorre a famosa Festa do Divino Espírito Santo, a mais tradicional festa do município, ocasião em que se realizam as cavalhadas simbolizando os combates entre Mouros e Cristãos. 
Pioneiro foi também em Pirenópolis, a instalação da Rádio Comunitária. A Rádio Jornal Meiaponte, que foi ao ar pela primeira vez em agosto de 1988, e depois de dois meses de experiência, somente à noite, passou a funcionar 17 horas por dia, contando com mais de 40 pessoas, que semanalmente colocavam a emissora no ar.

O histórico administrativo de Pirenópolis evolui da seguinte forma: em 1732 foi criado o Distrito de Meia Ponte, cuja sede foi elevada à categoria de Arraial. Em julho de 1832, o Arraial foi elevado à Vila, e a primeira Câmara Municipal foi instalada em abril de 1833. Em agosto de 1853, a Vila de Meia Ponte foi promovida a Cidade. Pelo Decreto n 181 de 27 de fevereiro de 1890, do Governo de Rodolfo Gustavo da Paixão, a cidade de Meia Ponte passou a denominar-se Pirenópolis, e desde 1850 é sede da Comarca.

\section{Localização e Acessos}

O município tem uma área territorial de $2.182 \mathrm{~km}^{2}$. Está localizado na microrregião denominada Planalto Goiano. Faz limite ao Norte com os municípios de Goianésia e Vila Propício, a Oeste com Jaraguá, São Francisco de Goiás e Petrolina de Goiás, ao Sul com Anápolis e a Leste com Abadiânia, Corumbá de Goiás e Cocalzinho de Goiás.

A cidade de Pirenópolis está a uma distância de 150 km de Brasília, ligada pela BR 070 até Cocalzinho, seguida pela BR 414 até Corumbá e pela GO 225, e de 120 km de Goiânia, ligada pela BR 153 até Anápolis, seguida pela BR 414 até Corumbá e novamente pela mesma GO 225 até Pirenópolis. Todas asfaltadas e em bom estado de conservação. Outro acesso que liga Goiânia a Pirenópolis é pela BR 153 até o trevo que conecta com a GO 431, também toda pavimentada. Desde Cocalzinho a Pirenópolis há um acesso por estrada não pavimentada, passando pelo Pico dos Pireneus e cruzando o Parque Estadual dos Pireneus.

A sede do município tem como coordenadas geográficas $15^{\circ} 23^{\prime} 47^{\prime \prime}$ de Latitude Sul e 4705’59” de Longitude Oeste. 


\section{Relevo e Hidrografia}

O relevo do município é bastante acidentado, com morros e vales de rara beleza, variando a altitude em 700 metros em seu ponto mais baixo, até os 1.385 metros no Pico dos Pireneus, o ponto mais alto da região. Este pico está situado na Serra dos Pireneus, que compõe o grande divisor de águas que separa as bacias Amazônica e do Prata.

As águas que percorrem o território de Pirenópolis são quase que totalmente da bacia Amazônica, exceto as do rio Corumbá pertencente à bacia do Prata. A combinação do relevo com a abundância de rios e córregos de águas cristalinas, formam inúmeras cachoeiras e balneários próprios à exploração turística. Os rios mais importantes são: o Rio das Almas, o Rio do Peixe e o Rio das Pedras que, juntando-se ao Rio Maranhão, vão alimentar a represa de Serra da Mesa.

Com relação às reservas minerais, a unidade estratigráfica distinta em Pirenópolis corresponde ao Grupo Araxá, conjunto metamórfico Pré-Cambriano, constituído de micaxistos, xistos verdes, filitos e quartzitos. Isso aloja concentrações de ouro, rutilo e esmeralda, além dos próprios quartzitos utilizados como rochas de revestimento, conhecidos como Pedra de Pirenópolis.

\section{Aspectos Econômicos}

A economia hoje está baseada nas atividades de agropecuária; na exploração de pedras ornamentais e quartzitos para uso na construção civil; no comércio e no turismo.

A exploração de pedras, que tem sido um dos pilares da economia, por um lado trás recursos para o município, por outro, fere profundamente o equilíbrio ecológico e visual de significativas áreas nas imediações da cidade. 
O turismo vem crescendo de uma forma significativa. Apesar de o município não adotar uma política de arrecadação com esta atividade, a atividade comercial e a prestação de serviços está demonstrando crescimento tanto em número como em qualidade.

\section{Áreas Protegidas}

*Parque Estadual da Serra dos Pireneus - Com área de 2.833,26 hectares, perímetro de 28.118,60 metros, situado entre os paralelos $15^{\circ} 46^{\prime} 45^{\prime \prime}$ e $15^{\circ} 50^{\prime} 08^{\prime \prime}$, e os meridianos 4848’30” e 4853’10”, atingindo os municípios de Pirenópolis, Cocalzinho e uma pequena parcela do município de Corumbá. Encerra em sua área, as nascentes do rio das Almas e do rio Corumbá e tem como ponto culminante o Pico dos Pireneus.

*Reserva Particular de Patrimônio Natural - RPPN - Existem no município cinco RPPN’s, já homologadas pelo IBAMA, que totalizam a área de 1.315,51 hectares. São elas: Santuário de Vida Silvestre Vagafogo, Fazenda Arruda, Fazenda Gleba Vargem Grande I, Santuário de Vida Silvestre Flor das Águas e Reserva Santuário de Gabriel.

*Área de Proteção Ambiental - APA Pireneus - Criada para proteger a região serrana e o entorno do Parque Estadual dos Pireneus, abrangendo os municípios de Pirenópolis, Corumbá e Cocalzinho, com aproximadamente 22.000 hectares e perímetro de 73.400 metros.

*Parque Ecoturístico e Cultural Várzea do Lobo (particular) - A mais recente iniciativa de uma proposta diferenciada é a criação do Parque Ecoturístico e Cultural Várzea do Lobo, com área de aproximadamente 1000 hectares. Projeto a ser implantado pela Sociedade Soto Zen do Brasil, com a construção de um Mosteiro onde funcionará a sede da Escola Zen Budista da América Latina. Oferecerá também, entre outras, opções de ecoturismo, SPA, Faculdade de Medicina Búdica, Escola de Filosofia Budista, etc. Esta área está localizada na região da Serra das Araras, repleta de belezas naturais, inúmeras cachoeiras, canyons e piscinas naturais de águas cristalinas. 


\section{CONDIÇÕES GERAIS PARA O TURISMO}

Dos municípios que compõem o Ecomuseu do Cerrado, Pirenópolis é o que oferece as melhores condições para o turismo. Isto tem suas razões: já no século XIX, quando os viajantes dirigiam-se ao Centro-Oeste brasileiro, Pirenópolis era lugar de parada obrigatória, pois foi um centro comercial importante e oferecia condições de hospedagem a seus visitantes.

Passado quase um século, volta Pirenópolis ao cenário das visitas, por muitos anos recebendo seus hóspedes na Pensão do Padre Rosa, famosa pelos mais de 30 pratos de comida tradicional goiana da melhor qualidade, e mais de 15 espécies de doces. Com a pavimentação asfáltica da GO 225 o turismo cresceu.

\section{Atrativos Naturais}

Pirenópolis é muito bem servido com relação aos atrativos naturais. Muitos córregos e rios aproveitam o relevo variado para formar cachoeiras e balneários que atraem turistas pela sua beleza. Em determinados trechos dos rios, as corredeiras possibilitam atividades esportivas como canoagem, bóia cross e rafting.

Os morros e serras, muitos deles cortados por estradas, algumas bandeirantes, propiciam o acesso a mirantes com visuais panorâmicos em ângulos de $360^{\circ}$. É muito rico, também, o aspecto histórico manifestado em diversos locais, como lavras de ouro, caminhos de pedra feitos pelos escravos nos séculos XVIII e XIX e resquícios de antigas povoações, como é o caso das ruínas próximas à Cachoeira do Abade.

\section{Atrativos Históricos e Culturais}

Pirenópolis é muito rica também em atrativos históricos e culturais. Há diversos prédios antigos que abrigam museus, igrejas e outras instalações, além que, a cidade é um atrativo como um todo, pois são inúmeras as casas antigas que foram adaptadas para pousadas, restaurantes e comércio em geral. Suas ruas e becos dão um ar bucólico à cidade, levando o 
turista a sentir-se também um personagem da história.

Os principais atrativos são:

*Matriz de Nossa Senhora do Rosário - Construída entre 1732 e 1736. É um dos mais antigos monumentos sacros do estado e o único que subsiste em sua forma original desde o tempo dos bandeirantes. Foi restaurada recentemente e está aberta à visitação.

*Igreja Nosso Senhor do Bonfim - Construída entre os anos 1750 e 1754. Em 1755, o Sarjento-Mór Antônio José dos Campos fez vir de Salvador a imagem de Nosso Senhor do Bonfim, que ali se encontra até hoje. A Igreja mantém seu estilo original, apesar de ter sido alterado entre os anos 1887 e 1907, quando suas fachadas coloniais receberam influências de um estilo neogótico.

*Casa de Câmara e Cadeia - Construída nos anos 1916 a 1919, é cópia da antiga Casa de Câmara e Cadeia que se localizava no Largo da Matriz, construída em 1733 e posteriormente demolida. Foi o primeiro prédio nesse estilo, construído em Goiás.

*Theatro de Pyrenópolis - Construído em 1889 com a cooperação da comunidade, tendo sua fase áurea no início do século. Entre 1945 e 1982, funcionou como cinema, depois serraria e mais tarde como fábrica de móveis, voltando à comunidade após sua restauração, em 1982. Restaurado recentemente, está integrado a um corredor cultural, juntamente com o espaço do Cine Teatro Pirenópolis, em restauração.

*Igreja Nossa Senhora do Carmo - Edificada no ano de 1750. De construção modesta e menor que as outras, mantém seu estilo primitivo, apesar das reformas que alteraram temporariamente sua fachada. Hoje funciona ali o Museu de Arte Sacra, que conta em seu acervo, restos da extinta Igreja Nossa Senhora dos Pretos.

*Museu da Família Pompeu - Casarão do século XVIII, construído pelo Comendador Joaquim Alves de Oliveira. Funciona um museu particular onde pode ser visto boa parte da história de Pirenópolis através de fotos, instrumentos, peças e jornais. No local funcionou, em 1830, a sede do primeiro jornal de Goiás “A Matutina Meiapontense”.

*Museu das Cavalhadas - Museu particular onde pode ser vista uma boa parte da história das Cavalhadas através de indumentárias, objetos e fotos.

*Cine Teatro Pireneus - Construído em 1929 pelo Padre Santiago Uchoa em estilo Neoclássico. Em 1936 sua fachada foi alterada para o estilo art Decó. Hoje está em processo 
de restauração.

*Pousada Walqueriana - Casarão tombado pelo IPHAN, onde as 16 suítes são equipadas com mobiliário de época e funciona um antiquário com mais de 1000 peças.

*Sala de Exposições da Casa do IPHAN - Espaço cultural aberto para exposições, palestras, lançamento de livros entre outros eventos.

*Ponte sobre o Rio das Almas - Existe desde a fundação do Arraial e motivo de seu antigo nome, Meia Ponte.

Na zona rural, são significativos os seguintes atrativos histórico-culturais:

*Santuário de Vida Silvestre Vagafogo - Oferece passeios em trilhas interpretativas na mata ciliar, informações sobre o cerrado e um "brunch” com aproximadamente 40 itens, produzidos quase todos, na própria fazenda.

*Fazenda Babilônia - Casa de Engenho construída em 1800, tombada pelo IPHAN. Abrigou em sua senzala cerca de 200 escravos com suas famílias. Oferece informações sobre a história da fazenda e um café goiano com aproximadamente 30 itens.

*Fazenda Caiçara - Antiga fazenda onde se pode ver um engenho com seus diversos ambientes, ainda em funcionamento.

*Recanto da Mata - Lavras de Ouro - Lavras do século XVIII, intocadas desde aquela época.

*Cidade de Pedras - Sede da Companhia Goyana de Mineração, construída nos anos 1880, restando vestígios das construções feitas na época.

\section{CALENDÁRIOS DE EVENTOS}

O município de Pirenópolis possui uma extraordinária riqueza em atrativos culturais, muitas provenientes das tradicionais festas religiosas, mescladas com elementos profanos, que dão originalidade aos eventos. As festas mais tradicionais são a Festa do Divino Espírito Santo e a Festa dos Pireneus.

No Estado de Goiás, a primeira Festa do Divino aconteceu em Pirenópolis, ainda Meia Ponte, no ano de 1819. É uma festa que dura 12 dias, culminando com as Cavalhadas. Tem trazido pessoas de todo o Brasil e de diversas partes do mundo, dada a sua beleza e encenação. Já foi motivo de filmes, vídeos e de Escola de Samba. 
A Festa dos Pireneus é realizada na noite de lua cheia de julho. Uma procissão sai da cidade, levando a imagem da Trindade e dirige-se à capela situada no pico mais alto dos Pireneus, onde é realizada uma missa. A festa acontece no sopé do morro, onde a cidade acampa e se diverte com música e bebida.

A particularidade das festas de Pirenópolis é a participação de toda a população, independente de situação financeira. As crianças participam ativamente em diversos momentos, interiorizando seu conteúdo desde cedo.

O Calendário de Festas contempla todo o município, acontecendo praticamente em todo o ano. *Festa de São Sebastião - Em 20 de janeiro. Festa religiosa, com novena, procissão e leilões. Tem mais de 200 anos de tradição, e atrai um público regional.

*Semana Santa - Um dos principais feriados sob o ponto de vista do turismo. A cidade recebe, além dos turistas das localidades próximas, muitos familiares que residem em outras localidades. A cidade fica muito bonita.

*Corpus Christi - É outro feriado importante sob o ponto de vista turístico, pois sempre cai numa $5^{a}$ feira, gerando assim, um movimento maior devido ao feriado prolongado.

*Festa do Divino - Acontece todo o ano, desde 1826, 50 dias após o Domingo de Páscoa. Durante os sete dias que antecedem a Festa, se desenvolve a Folia na Roça. Atrai um público regional, mas é crescente o número de turistas de outros estados que a freqüentam.

*Festa de São João - Pequenos movimentos isolados nas fazendas e povoados. Público local.

*Festa do Divino Pai Eterno de Caxambu - Ocorre em junho há mais de 50 anos, tendo como atração principal o desfile de carros de boi. Atrai um público regional. Caxambu é um povoado distante $25 \mathrm{~km}$ de Pirenópolis.

*Festa do Morro - Ocorre na lua cheia de julho, no Pico dos Pireneus, com procissão, missa no pé do morro e piquenique ao luar. Público jovem, regional.

*Festa do Divino em Lagolândia - Acontece no $3^{\circ}$ domingo de julho, durante 2 dias, a 25 km da cidade. Reúne um público regional e alguns turistas de outras localidades.

*Festa da Capela - Em 26 de julho com novena, romaria e acampamento. Chega a durar até 12 dias.

*Festa da Placa - Em agosto. É religiosa, atrai público regional. O povoado de Placa fica a 20 
km da cidade.

*Festa Nosso Senhor do Bonfim - Em setembro. É uma festa com tradição de mais de 200 anos. Atrai público regional.

*Exposição Agropecuária - Em setembro, na cidade. Reúne público regional.

Um grande atrativo cultural de Pirenópolis é a famosa culinária goiana, tanto pelas comidas regionais constantes dos cardápios de diversos restaurantes da cidade, como pela qualidade de seus quitutes. Os frutos do cerrado estão sendo utilizados por diversos quituteiros da região, na forma de conservas, doces cristalizados, geléias, licores, e outros.

Além deste rico calendário festivo e gastronômico, vem ocorrendo em Pirenópolis inúmeras exposições de obras de arte, lançamento de livros, concertos, teatro e shows.

Nos últimos cinco anos, Pirenópolis foi cenário de 4 longas-metragens, três curtas e da minissérie independente de televisão Luar do Sertão, ainda inédito. A última atividade relacionada com TV foi a gravação da novela Estrela-Guia.

Pirenópolis vem se firmando como importante sítio turístico no Estado de Goiás. O comércio, os atrativos e os serviços em geral multiplicam-se, demonstrando o quanto a comunidade está respondendo aos novos paradigmas da economia do município.

Os atrativos naturais já sofrem os efeitos degradantes por falta de planejamento e adoção de uma política correta quanto à exploração. A extração de pedras próxima às margens dos rios, também trazem efeitos negativos. Locais que outrora permitiam balneabilidade e a prática de esportes aquáticos, estão assoreados impedindo o lazer e esportes, além do comprometimento do aspecto visual de significativas áreas na paisagem local.

As cachoeiras e outras opções de atividades aquáticas existentes ao longo dos córregos que cortam o município, assim como os caminhos históricos, as trilhas para cavalgadas, mountain bike e off road, vêm atraindo cada vez mais ecoturistas e turistas de aventura, transformando Pirenópolis em Pólo de Ecoturismo do Estado de Goiás. 
Os atrativos históricos e culturais são significativos. Muitos prédios passaram por restauração recente e estão abertos à visitação. Alguns, porém, têm sua visitação prejudicada por falta de organização.

Há muitos vestígios da exploração aurífera, principalmente às margens do Rio das Almas. Alguns proprietários perceberam que tais testemunhos poderiam trazer-lhes benefícios e preservaram-nos ao longo dos tempos, transformando-os em importantes atrativos educativos. Outros não tiveram a mesma visão e destruíram centenas de metros de lavras bandeirantes para comercializar o cascalho.

Os campings proliferaram-se também. Alguns organizados, com bons atrativos, outros carentes de estrutura básica. A capacidade de acomodação em campings é de aproximadamente 6.000 pessoas.

Existem muitas outras opções de passeios nas imediações de Pirenópolis, que ainda não se encontram em roteiros, mas têm condições de serem explorados. Um exemplo é a região da Terra Nostra, com diversas casas bem equipadas, caminhos pela mata preservada, córregos e outras opções de lazer. Há necessidade de um levantamento com os proprietários da área para identificar quem tem interesse e o que pode oferecer. Próximo a Terra Nostra encontra-se o pequeno povoado de Bom Jesus, onde residem alguns artesãos da prata.

Pirenópolis também oferece ótimas condições para iniciativas esportivas e de aventura. Recentemente aconteceu o Eco Cerrado 2000 - Circuito Centro-Oeste de Corrida de Aventura, com diversas modalidades de esporte. Este evento foi organizado de tal forma para que os participantes conhecessem muitas belezas naturais existentes no município.

Há, portanto, um relativo equilíbrio entre hospedagem em hotéis e pousadas, alimentação e capacidade de carga nos atrativos. A atividade turística organizada em Pirenópolis, já é em número significativo, pode perfeitamente atender a uma demanda plena sem causar maiores transtornos. 
Cabe ressaltar ainda, que em Pirenópolis movimenta um universo de aproximadamente 1300 pessoas entre proprietários de estabelecimentos, empregados, artistas, artesãos e outros prestadores de serviços diretamente ligados ao turismo. Este número é muito significativo, pois representa mais de $10 \%$ da população residente na zona urbana do município.

\section{SANTO ANTÔNIO DO DESCOBERTO}

\section{Breve Histórico}

Das bandeiras do século XVIII, houve uma comandada por José Pereira Lisboa que, seguindo o roteiro de Anhangüera, adentrou pelas matas da região em busca de riquezas. Segundo a lenda, ao descobrirem uma pepita de ouro no estômago de um animal que acabavam de abater, resolveram montar acampamento na beira do rio e iniciaram o garimpo. Assim surgiu a Fazenda Montes Claros, nome originado pela claridade que o morro emitia ao nascer do sol, destacando-se dos demais. É o atual morro do cruzeiro.

Passado algum tempo, a escassez do ouro levou desavenças no acampamento, só interrompida quando encontraram, junto a um pé de Angico, a imagem do Santo Antônio de Lisboa, Santo de devoção da maioria dos portugueses que aí se encontravam. Ergueram, então, uma pequena capela que motivou romarias de pessoas que vinham de diversos lugares para conhecerem o Santo descoberto. A partir de então, o rio recebeu o nome de Rio Descoberto e a fazenda de Santo Antônio do Descoberto, que veio a ser considerado povoado somente no século XX.

Em 1964 o povoado foi promovido a Distrito, e em 14 de maio de 1982, pelo Decreto Estadual $n^{\circ}$ 9167, adquiriu sua autonomia política tornando-se município independente de Luziânia.

Passaram pelo local bandeirantes e viajantes, naturalistas - Auguste de Sait-Hilaire descreve o Morro do Tição, o Morro da Cruz e dá outras referências, e foi ponto de passagem também para a Coluna Prestes quando de suas andanças pelo Goiás, deixando suas marcas no local denominado Antinha. 


\section{Localização e Acessos}

O município tem uma área territorial de $938 \mathrm{~km}^{2}$. Está localizado na microrregião denominada Planalto Goiano. Faz limite ao Norte com o município de Águas Lindas de Goiás, a Oeste com Cocalzinho, Corumbá e Alexânia, ao Sul com Luziânia e a Leste com o Distrito Federal.

A cidade está localizada às margens do Rio Descoberto, a uma distância de 50 km de Brasília e a 175 km de Goiânia. A sede do município tem como coordenadas geográficas 1556’45” de Latitude Sul e 48¹5’38” de Longitude Oeste.

\section{Relevo e Hidrografia}

O relevo do município é acidentado, apresentando altitudes superiores a 1.100 metros. A altitude da sede do município é de 912 metros.

As águas que percorrem o seu território pertencem à bacia do Prata. A combinação do relevo com a abundância de rios e córregos formam inúmeras cachoeiras, algumas com mais de 30 metros de altura.

Santo Antônio do Descoberto tem suas divisas com os outros municípios e com o Distrito Federal demarcadas pelos seguintes rios: dos Macacos, Areias, Corumbá e Descoberto.

A predominância de solos é de latossolos vermelhos e amarelos.

\section{Aspectos Econômicos}

A atividade econômica predominante é o comércio, representado cerca de 1.200 estabelecimentos, seguido pela indústria, com 51 instalações.

Na Cidade Eclética, a atividade econômica se baseia principalmente na pecuária, voltada ao 
gado leiteiro; no aviário, há parceria com a empresa Sofrango, onde uma parcela da produção (ovos e abates) se destina ao consumo da comunidade; na agricultura há cultivo de arroz, milho, feijão, soja, frutas, hortaliças, e outras.

Embora a extensão das terras pertencentes à Fraternidade seja superior a 1.500 hectares, a escala das criações e cultivos, é de subsistência, sendo que, algum eventual excedente é negociado em troca de outros gêneros em falta na comunidade. Soma-se a essas produções locais as doações feitas por membros e simpatizantes da Fraternidade que regularmente chegam à Cidade Eclética provenientes de diversos pontos do país.

\section{Áreas Protegidas}

Existe apenas uma área protegida no município, é uma Reserva Particular localizada na região de Santa Rosa.

\section{CONDIÇÕES GERAIS PARA O TURISMO}

Apesar do município conter diversos atrativos naturais e ter uma história que remonta ao período da ocupação do Centro-Oeste, estas características não se traduzem em opções para o turismo.

\section{Atrativos Naturais}

Em função do relevo acidentado e dos rios e córregos que cortam o município, existem diversos atrativos naturais, porém, nenhum está aberto à visitação.

No Rio dos Macacos e no Rio Areias, há possibilidade de se praticar esportes aquáticos, como também, caminhadas em trilhas existentes pela região.

Outro esporte que pode ser incentivado, são passeios de moto e jipe pelo município, desde que feitos de uma forma organizada. 
Um único atrativo aberto ao público é o Pesque e Pague Bom Amigo, da Comunidade Eclética Espiritualista Universal, localizada na saída da Cidade Eclética, a 02 km do asfalto.

\section{Atrativos Históricos e Culturais}

*Morro dos Montes Claros, atual Morro da Cruz - Localizado próximo à cidade, onde foi implantada uma cruz em seu topo, tendo servido outrora como cemitério.

*Capela de Santo Antônio - Capela erguida em homenagem à imagem de Santo Antônio de Lisboa, encontrada ao lado de um de angico, onde ocorre anualmente a Festa do Padroeiro.

*Lavra de Ouro - Às margens do Rio Descoberto, resquícios da mineração em valas profundas, podendo tornar-se um belo atrativo.

\section{CALENDÁRIO DE EVENTOS}

*Festa do padroeiro da cidade, Santo Antônio, nos dias $1^{\circ}$ a 13 de junho.

*Festa do Peão de Boiadeiro - Realizada anualmente nos dias 28 a 31 de setembro.

A história de Santo Antônio do Descoberto inicia com a passagem dos bandeirantes pela região, no início do século XVIII, na mesma época do surgimento de Pirenópolis e Corumbá. Porém, enquanto nessas houveram a fixação do homem devido à quantidade de riquezas encontradas, Santo Antônio não evoluiu, permanecendo como local de passagem e de romaria. A cidade cresceu muito nos últimos anos devido à sua proximidade com Brasília. Este inchaço urbano, interferiu profundamente na paisagem, agredindo os recursos naturais.

Apesar dos inúmeros atrativos naturais existentes no município, a falta de uma política de incentivo para explorá-los não permite que a comunidade tome conhecimento e usufrua desses locais. Se de um lado não há exploração, por outro, estes locais estão preservados.

Não são muitos os atrativos históricos e culturais, porém são significativos para se desenvolver atividades educativas. Os três atrativos citados podem se transformar num excelente roteiro, 
estimulando a comunidade, tanto estudantil quanto a população em geral, a mergulhar um pouco na sua história. As duas fazendas antigas existentes próximo à cidade podem, também, se transformar em atrativos históricos.

O presente relatório contribui para um futuro planejamento de empreendimentos ecoturísticos na região do Ecomuseu do Cerrado, no qual podem ser aproveitados os potenciais já existentes em cada localidade que o compõe. Assim, os recursos naturais, movimentos culturais, calendários de eventos religiosos e festivos e a própria história poderão incrementar ações que estimulem esse aproveitamento, como também, treinamento da mão-de-obra da população visando a sustentabilidade para a realização da atividade econômica. Outras iniciativas deverão ser complementadas, tais como, o levantamento de dados físicos, econômicos, sociais e culturais que são requisitos para o inventário da região. Também estudos para trilhas ecológicas guiadas, fomento da educação ambiental, valoração de artesanato e estímulo para investimento de cada segmento profissional, visando a capacitação de recursos humanos para melhor atendimento aos ecoturistas, o que favorecerá geração de renda revertida em melhorias para as cidades.

\section{3-'IODIVERSIDADE DO CERRADO}

O nome Cerrado tem dois significados: cerrado (sentido amplo), ou a vegetação que ocupa principalmente o Brasil Central e inclui todas as comunidades vegetais da região como o cerrado, o cerradão, as matas ciliares, de galeria e matas secas, etc., e o cerrado (sentido restrito), que se refere à comunidade mais comum na sua paisagem.

Cerrado é uma das regiões de maior BIODIVERSIDADE do planeta e cobre 25\% do território nacional. Estimativas apontam mais de 6.000 espécies de árvores e 800 espécies de aves, além de grande variedade de peixes e outras formas de vida. Calcula-se que mais de $40 \%$ das

\footnotetext{
${ }^{2}$ (Dados obtidos no caderno técnico: "Prevenção e Combate aos incêndios florestais em Unidades de Conservação" - GDF. SEMARH. Brasília: Athalaia Gráfica e Editora, 2004.)
} 
espécies de plantas lenhosas e 50\% das espécies de abelhas sejam endêmicas, isto é, só ocorrem nas savanas brasileiras. Devido a esta excepcional riqueza biológica, o cerrado, ao lado da Mata Atlântica, é considerado um dos hotspots mundiais, isto é, um dos biomas mais ricos e ameaçados do Planeta.

Vanzolini (1963) reconheceu que o Cerrado ocupa posição geográfica central na América do Sul e tem por vizinhos a noroeste a Floresta Amazônica e a sudeste a Mata Atlântica, ambas vegetações mais úmidas, e a nordeste a Caatinga e a sudoeste o Chaco, ambas vegetações mais secas. Eiten (1972) demonstrou que o Cerrado também apresenta níveis de precipitação intermediários na América do Sul, entre 700 e 1800 mm/ano, o que possibilita a ocorrência de espécies vegetais das quatro vegetações vizinhas, das florestas Amazônica e Atlântica, da Caatinga e do Chaco, além das suas próprias, o que resulta em elevada diversidade em espécies vegetais.

\section{-Vegetação:}

Segundo Mendonça et al. (1998), o número de espécies vegetais do Cerrado é de mais de 6.500 espécies nativas, distribuídas em 170 famílias e 1.144 gêneros, o que representa cerca de

26\% dos 4.200 gêneros estimados para a América do Sul e 63\% das 9.300 espécies estimadas para a Caatinga, o Cerrado, o Chaco, os Lhanos e o Pantanal (Gentry et al.,1997).

As paisagens naturais são cada vez mais raras no Brasil Central. Sua importância na qualidade de vida das populações locais passa da manutenção do volume e da qualidade da água produzidas na região, da estabilidade climática, com a regulação das chuvas, temperatura, infiltração da água nos solos, até aspectos sociais e culturais, como culinária, artesanato, conhecimentos tradicionais, que estão desaparecendo juntamente com a perda da cobertura vegetal nativa. Gerações mais novas não conhecem o Cerrado, e assim também não conhecem as tradições regionais.

- As comunidades vegetais e sua associação com os solos: 
.Formações campestres: onde os solos são rasos e há restrições para o crescimento das raízes, ocorrem as formações campestres (Ribeiro e Walter, 1998), comunidades com número reduzido de árvores e arbustos onde predomina a vegetação herbácea, com $0,5 \mathrm{~m}$ a $0,7 \mathrm{~m}$ de altura (Eiten, 1972, 1991, Adómoli et al., 1985). Esse grupo inclui:

a)campo cerrado: com a presença de arbustos e pequenas árvores que ocupam menos de $10 \%$ da paisagem.

b)campo sujo: com arbustos e árvores mais baixos e em menor quantidade. O campo sujo úmido ocorre nas áreas mais planas e baixas, e o campo sujo seco, nas áreas inclinadas e mais secas.

c)campo limpo-úmido: nas baixadas e seco nas encostas, não apresenta arbustos ou árvores. d)campo rupestre: com pequenas árvores e arbustos, em altitudes maiores que $1.000 \mathrm{~m}$ em solos com afloramentos de rochas.

e)campo de muruduns: áreas úmidas com elevações no terreno, o que resulta em maior aeração do solo e na conseqüente colonização por pequenas árvores e arbustos do Cerrado (Haridasan, 1991; Oliveira-Filho, 1992).

Onde os solos são profundos e não há impedimentos para o crescimento das raízes ocorrem as formações savânicas ou florestais (Ribeiro e Walter, 1998), de acordo com a maior ou menor disponibilidade de água e nutrientes nos solos. Esses grupos incluem:

-Formações Savânicas:

Cerrado sentido restrito: caracterizada pela presença de árvores e arbustos tortuosos, com 3m a $7 \mathrm{~m}$ de altura, que cobrem de $10 \%$ a $50 \%$ da área. Está principalmente associado com solos profundos nas áreas das Chapadas (Haridasan, 1991).

-Formações Florestais: onde a densidade de árvores resulta no entrelaçamento das copas vizinhas e no sombreamento do solo, o que reduz o crescimento de plantas herbáceas e gramíneas de sol.

.Cerradão- representado por apenas pequenas manchas associadas a solos profundos onde árvores de $8 \mathrm{~m}$ a $15 \mathrm{~m}$ de altura cobrem $70 \%$ a $100 \%$ da área, o que limita o desenvolvimento da vegetação herbácea. 
.Matas secas decíduas, semidecíduas ou sempre-verdes- associadas aos solos com maior disponibilidade de nutrientes (Eiten, 1972; Adámoli et al., 1985). As matas decíduas, associadas aos solos mais rasos de afloramentos de rochas calcárias, e as semidecíduas ou sempre-verdes, associadas a solos mais profundos. Nessas matas, as árvores atingem $15 \mathrm{~m}$ a $25 \mathrm{~m}$ de altura e cobrem de $70 \%$ a $100 \%$ da área.

.Matas de galeria- ocorrem no fundo dos vales ao longo dos córregos e pequenos rios onde o entrelaçamento das copas da árvores em ambas as margens sombreia o curso de água. As árvores atingem $15 \mathrm{~m}$ a $25 \mathrm{~m}$ de altura e cobrem $70 \%$ a 100\% da área. Essas matas contêm grande parte da riqueza em espécies na região.

.Matas ciliares- ocorrem no fundo dos vales ao longo de rios de maior porte onde as copas das árvores em ambas as margens não se tocam. As árvores atingem $15 \mathrm{~m}$ a $25 \mathrm{~m}$ de altura e cobrem $70 \%$ a $100 \%$ da área.

.Veredas- colonizam as áreas planas e permanentemente com solos hidromórficos e mostram a predominância de Mauritia flexuosa L. , o buriti.

O que caracteriza o Cerrado é a sua estrutura, composta sempre de dois estratos peculiares: um é o estrato ou andar arborescente, de pequenas árvores tortuosas, espaçadas e dotadas de cascas espessas e comumente corticosas, macias à unha; outro é formado de gramíneas, subarbustos e arbustos - é o estrato baixo ${ }^{3}$.

De julho a setembro, do meio para o fim da estação seca no cerrado, a vegetação parece extremamente ressecada: as gramíneas ficam pardacentas e fáceis de queimar, o solo, exsicado e duro na superfície, as árvores, parcialmente desfolhadas - já que são semidecíduas durante a seca. O sol é intenso, o ar detém pequena cota de umidade; as folhas revelam-se grossas e rígidas pelo geral. Esse conjunto de evidências faz o observador não-técnico julgar que se

\footnotetext{
${ }^{3}$ Dados obtidos no livro: “Ecossistemas Brasileiros” RIZZINI- Carlos Toledo, FILHO, Adelmar F. Coimbra e HOAISS, Antônio. Enge-RIO, Engenhaia e Consultoria S.A - Editora Index, 1988. )
} 
encontra frente a uma vegetação adaptada sob condições de carência hídrica. E, no entanto, ela é realmente mesófila, apropriada para viver em ambiente dotado de água suficiente (e, por vezes, excessiva).

A seca é apenas atmosférica, limitada aos meses de meio de ano. Ademais, as chuvas são regulares de outubro a março. Registra-se que no cerrado, em virtude de tais reservas hídricas dos solos, a rebrotação das plantas sobrevém antes mesmo das chuvas - no final da estação seca -, acompanhado na floração abundante no final de setembro ou início de outubro.

O cerrado se recompõe fácil e rapidamente, após qualquer devastação natural ou antrópica. A rebrotação surge abundantemente, vinda das partes subterrâneas e - secundariamente - das sementes que perduravam latentes no solo.

Conhecem-se em torno de 700 espécies de árvores e arbustos na flora do cerrado. Essa flora tem um número apreciável de elementos oriundos da Mata Atlântica. São elementos correntios disso o ipê-branco (Tabebuia Alba), a erva-de-teiú (Casearia sylvestris), o pau-d’óleo (Copaifera lansdorffii), o Gonçalo-alves (Astronium fraxinifolium), a sucupira (Bowdichia virgilioides) e a ucuúba-vermelha (Virola sebifera).

O solo do cerrado pode ser arenoso, mas na maioria dos casos corresponde ao termo atual latossolo. Trata-se de um solo profundo, formado de argilas vermelhas ou amarelas, floculadas, muito agregadas, o que faz poroso e permeável. Ácido e pobre de nutrientes para os cultivos, tem excesso de óxidos de alumínio e ferro. Segundo seus componentes, os mais encontradiços são chamados latossolos vermelho-escuros e latossolos vermelho-amarelos, dependendo da cor dada neles pelo o teor do sesquióxido de ferro.

A ação da evaporação só faz diminuir a quantidade d’água contida no solo superficial; juntando-se a transpiração das plantas, a dessecação chega a descer 2m. Mas, no cerrado, é perceptível bem acima, sobretudo no latossolo vermelho-escuro. Há quem diga que a maior riqueza do cerrado é a imensa reserva de água. Vê-se que a evapotranspiração retira água, mas a dessecação que induz é apenas relativa, sem prejuízo ecológico. 
Tanto o solo quanto a vegetação sofrem efeitos do fogo. No solo, destrói-lhe a matéria orgânica superficial, rompe o seu ciclo e empobrece-o, reduz-lhe a capacidade de absorção da água, acabando, assim, por endurecê-lo, esterilizando-lhe a superfície, eliminando-lhe a microflora e a fauna edáficas. Ademais, apressa a queda das folhas, favorece o aparecimento precoce de folhagem nova: as árvores vão perdendo, em ritmo lento, as folhas, durante a seca, mas o fogo acelera esse processo. As queimadas ao final da seca são muito mais nocivas, pois a rebrotação e a floração estão em curso - acarretando a morte de muitas árvores.

As árvores resistem por virtude de suas cascas grossas ou corticosas. Como o fogo é rápido, pois as gramíneas e os galhos são bons combustíveis, as chamas costumam ser a causa de gemas adventícias, fora da posição normal, o que dá conta da formação de ramos irregulares, provocando a tortuosidade das árvores.

A rigor, no conjunto, o fogo não destrói o cerrado: prejudica-o, tão somente.

As madeiras úteis do cerrado brasileiro seriam numerosas, como a sucupira (Bowdichia virgilioides), o gonçalo-alves (Astronium fraxinifolium), a cabiúna-do-cerrado (Dalbergia violácea), a carne-de-vaca (Roupala brasiliensis), o pequizeiro (Caryocar brasiliense), o faveiro (Pterodon pubescens), o vinhático (Platymenia reticulata) e a aroeira-do-sertão (Astronium urundeuva).

Cortiça, no cerrado, é comum, mas com uma única condição: ser moída e prensada mediante cola, para o fabrico de lâminas isolantes destinadas à indústria do frio. O tanino procede, usualmente, do barbatimão (Stryphnodendron adstringens). Óleo para sabão cede o pequizeiro (Caryocar brasiliense). São muitos os frutos que poderiam ser aproveitados para a alimentação do homem. Vale a pena citar alguns, de que, pelo menos os habitantes comuns da terra, nos estamos cada vez mais culturalmente distanciando: a mangaba (Hancornia speciosa), os cajus (Anacardium spp.), o marolo (Annona crassiflora), o pequi (Caryocar brasiliense), o jatobá (Hymenaca stignocarpa), o baru (Dipteryx alata), a cagaíta (Eugenia dysenterica), a marmelada-de-cachorro (Thieleodoxa lanceolata), a fruta-do-lobo (Solanum lycocarpum) e muitos outros de maior ou menor prestabilidade. 
Ocorrem ainda aromáticos medicinais nesta vegetação. Dentre eles, há o mais famoso fármaco dos cerrados, a catuaba (Anemopaegma arvense). Maior valor, têm um cem número de plantas ornamentais, vulgares ou vulgarizáveis, tais como o algodoeiro-do-campo (Cochlospernum regium), o paratudo (Gomphrena officinalis), a tiborna (Himatanthus oleovata), o pau-santo (Kielmeyera coriacea e K. speciosa) e os ipês (Tabebuia caraíba e T. ochracea).

A fauna do cerrado caracteriza-se por um número relativamente reduzido de formas verdadeiramente endêmicas.

Dentre os mamíferos comuns ao ecossistema, podem ser citados diversos, tais como: tamanduás e tatus; tatu-bola, tatu-canastra, que facilmente atinge 50 quilos de peso.

Forma bem típica do cerrado é o tamanduá-bandeira. Tanto os tamanduás como os tatus desempenham um papel ecológico nas comunidades como controladores de cupins e de algumas formigas.

Há no cerrado, muitos morcegos insetívoros, mas existindo outros tipos de morcegos.

O número de primatas é muito reduzido. Apenas quatro espécies lhe são próprias: o bugio, um macaco-prego e dois sagüis.

Há no cerrado, importante família de ratos-do-mato. Outro roedor característico é a cotia, a paca, capivara comum nas proximidades dos rios, a capivara como o maior roedor do mundo, habitante de lugares onde haja concentração de água.

Dois porcos-do-mato - o queixada e o caititu - são comuns e não raro são vistos aos bandos na travessia de rios regionais.

O veado-campeiro e o veado-catingueiro vivem em formações de cerrados descampados. Esses e outros mamíferos, aves, répteis, batráquios, etc., são alimentos de vários predadores, dos quais o jaguar é o mais notável. Outros felinos regionais são: a suçuarana, a jaguatirica e vários gatos-do-mato. Diversos canídeos, como o lobo-guará, o cachorro-vinagre, a raposa-docampo e o cachorro-do-mato. 
Aves de vários tipos, vivem no cerrado, como as perdiz, a ema, a siriema, o tucanuçu entre outros vivem nesse ecossistema como a pomba asa-branca, jandaia, o papagaio-de-cabeçaamarela e araraúna.

Identificam-se mais de 260 espécies de répteis como sucuris, jararacas, cascavel e jibóia. Jabutis e cágados, dão ao cerrado razoável representação do grupo.

Por sua extensão, se têm notável representação de invertebrados, especialmente no entomofauna (fauna de insetos). Os cupins ou térmitas (Isoptera) desempenham importante papel, afetando a vegetação de duas formas: consomem partes selecionadas de plantas vivas e mortas, atuando no processo de decomposição e modificam certas propriedades dos solos, influenciando no crescimento das plantas. Próximo aos cupinzeiros, os solos apresentam-se mais ricos em nutrientes e mais úmidos.

Conforme o que relata o Almanaque Ecomuseu do Cerrado, esse bioma tem sido "severamente castigado pelas formas de ocupação humana tidas como economicamente rentáveis: primeiro a exploração predatória do solo e rios em busca das pedras preciosas, depois pelas vastas áreas desmatadas sem cuidado, para a criação intensiva de gado; ainda, a extração de pedra, areia e calcário, sem a preocupação com os efeitos danosos de assoreamento dos rios. As erosões, voçorocas, as queimadas, e os resíduos sólidos, fazem parte do panorama dos municípios do Ecomuseu do Cerrado.”

(Almanaque Ecomuseu do Cerrado)

-Invertebrados ${ }^{4}$ :

Em três ordens de insetos, Lepidóptera, Hymenoptera e Isoptera, o número de espécies estimado para o Cerrado é de 14.425 e representa 47\%da fauna estimada para o Brasil.

Ao contrário do tradicionalmente aceito para vertebrados, parece existir uma fauna de invertebrados típica do Cerrado e, especialmente, para copépodos, com uma alta proporção de espécies exclusivas do bioma.

\footnotetext{
${ }^{4}$ *Dados obtidos do livro: Biodiversidade Brasileira, MMA Brasília, 2002)
} 
As regiões com grutas e cavernas devem receber atenção especial para garantir a sobrevivência das espécies restritas a esses ambientes peculiares. As veredas, os campos úmidos e de murundu são também prioritários, pois apresentam alto grau de endemismo de espécies de invertebrados, evidenciado pelas espécies bênticas de copépodos.

Os limites das áreas protegidas já criadas também devem ser revisados, como o Parque Nacional da Chapada dos Veadeiros. O vão do Paranã e porções adjacentes ao parque abrigam muitas espécies de Lepidóptera do sul do Brasil que têm aí o seu limite norte de distribuição.”

-Biota Aquática:

A diversidade de espécies no Cerrado e no Pantanal pode ser exemplificada pelos dados de ictiofauna. Podendo ser encontrado cerca de 780 espécies de peixes.

Atualmente, apenas 0,44\% do Cerrado e do Pantanal, estão contemplados por Unidades de Conservação genuinamente aquática.

Os sistemas mais ameaçados na região e que devem ter prioridade compreendem as cabeceiras das bacias de drenagem e as planícies de inundação dos grandes rios. As veredas e os brejos de altitude estão incluídos nesta avaliação, pois são habitados por várias espécies anuais de distribuição muito restrita.

-Répteis e Anfíbios:

Como mostra a tabela, os dados existentes não são suficientes para uma estimativa do número de espécies.

Tabela 1: Número de répteis e anfíbios e seu status para o cerrado

\begin{tabular}{|l|c|c|}
\hline Répteis & Cerrado & Pantanal \\
\hline $\mathrm{N}^{\mathrm{o}}$ de espécies & 180 & 113 \\
\hline $\mathrm{N}^{\mathrm{o}}$ de espécies endêmicas & 20 & 05 \\
\hline $\mathrm{N}^{\mathrm{o}}$ de espécies ameaçadas & 15 & 15 \\
\hline
\end{tabular}




\begin{tabular}{|l|c|c|}
\hline Anfíbios & & $?$ \\
\hline $\mathrm{N}^{\mathrm{o}}$ de espécies & 113 & $?$ \\
\hline $\mathrm{N}^{\mathrm{o}}$ de espécies endêmicas & 32 & 3 \\
\hline $\mathrm{N}^{\mathrm{o}}$ de espécies ameaçadas & 3 & $?$ \\
\hline
\end{tabular}

-Aves:

Áreas como o planalto de Brasília, o vale do Paranã, a Chapada Diamantina e o vale do rio Araguaia foram todas consideradas como de interesse extraordinário para a conservação da avifauna do cerrado, por estarem representadas por uma ou mais Unidades de Conservação, não foram incluídas na análise de prioridades.

Recomendações:

.Migrações: estudos devem ser feitos para compreender os padrões de migrações das aves que vivem no Cerrado e no Pantanal. Foram documentados movimentos sazonais que incluem desde simples movimentos inter-habitats de pequena distância até movimentos intracontinentais de longa distância. De modo geral estima-se que cerca de 60 a 70\% da avifauna do Cerrado e Pantanal realizam algum tipo de movimento sazonal .

.Ninhais: o mapeamento e o monitoramento dos ninhais seria prioridade de estudo. Regiões que deveriam ser investigadas com mais detalhes incluem o vale do rio Paranã, o vale do rio Araguaia e os afluentes do rio Xingu.

.Comunidades especiais: a região não é homogênea. Ao contrário, ela é firmada por um mosaico de habitats bastante distintos. Os campos rupestres, os campos limpos úmidos, as florestas estacionais decíduas e semidecíduas, as florestas de galeria alagasse o cerradão ainda necessitam de melhores estudos para caracterização desses ambientes.

.Dados biológicos: a história natural da grande maioria das espécies é pouco conhecida. Para muitas espécies, mesmo informações básicas sobre a voz e as fases de plumagem não estão disponíveis. Estes dados biológicos básicos são essenciais para uma avaliação criteriosa de manejo para as áreas e mesmo para dimensionar as conseqüências das alterações antrópicas 
sobre a avifauna. Estimativas indicam que reservas com menos de 7.000 ha podem ser pouco funcionais para conservar parte significativa da sua biodiversidade original.

Tabela 2: número de aves encontradas no cerrado.

\begin{tabular}{|l|c|}
\hline $\mathrm{N}^{\circ}$ de espécies & 837 \\
\hline $\mathrm{N}^{\mathrm{o}}$ de espécies com reprodução no bioma & 759 \\
\hline $\mathrm{N}^{\mathrm{o}}$ de espécies ameaçadas & 33 \\
\hline $\mathrm{N}^{\mathrm{o}}$ de espécies endêmicas & 29 \\
\hline $\mathrm{N}^{\mathrm{o}}$ de espécies endêmicas ameaçadas & 14 \\
\hline
\end{tabular}

-Mamíferos:

As espécies de mamíferos com ocorrência no cerrado totalizam 195, sendo 18 endêmicas. As espécies mais vulneráveis aos processos de degradação são as de topo de cadeias tróficas, como os carnívoros, bastantes sensíveis à redução e a fragmentação do habitat. Os ungulados têm sido alvo interno de caça. As espécies especialistas de habitats com distribuição restrita, particularmente aquelas de habitats insulares, como as veredas e as florestas semidecíduas, também devem receber atenção especial para a sua preservação. Das espécies com ocorrência no Cerrado e no Pantanal, 16 estão incluídas na lista oficial de espécies ameaçadas de extinção.

A caça, apesar de geralmente ocorrer em pequena escala, provoca efeitos sensíveis sobre a densidade populacionais de várias espécies, como onças no Pantanal.

\section{1-USO E OCUPAÇÃO}

De acordo com a autora Pinto, a ocupação humana no Cerrado brasileiro

“Teve início há cerca de 11.000 anos, com caçadores e coletores adaptados às condições ambientais. Posteriormente as populações indígenas passaram a desenvolver a agricultura diversificada até o século XVIII, quando a região foi ocupada pelo homem branco em busca do ouro, pedras preciosas e índios. Nessa ocasião foram fundadas numerosas cidades, ao mesmo tempo em que ocorria a degradação do meio ambiente, localizada 
nas áreas de exploração dos recursos minerais. Findo o ciclo da mineração a região do Cerrado permaneceu economicamente dedicada à criação extensiva do gado e à agricultura de subsistência.” (Pinto 1990, p.3)

Na década de cinqüenta, o Planalto Central era praticamente isolado dos locais que já tinham maior número populacional e economicamente mais adiantados, no Brasil. Entretanto, com a implementação de Brasília, em abril de 1960, para o centro do país, provocou mudanças radicais na paisagem do Cerrado, com conseqüências marcantes nos aspectos físicos, biológicos, sociais e culturais. As antigas cidades têm-se modificado constantemente e se tornado locais que o desenvolvimento agrícola está ficando em primeiro lugar.

Do ponto de vista ambiental, o Cerrado vem sofrendo principalmente com o crescimento desordenado e suas terras estão sendo ocupadas constantemente. Muitos espaços estão sendo desmatados e a fauna não têm encontrado seus lugares de refúgio como também, a vegetação nativa, como as veredas e matas ciliares, vêm sendo alvo de extermínio.

“...As antigas cidades da região, quase todas criadas em torno da corrida do ouro, essencialmente no início do século XVIII, além de importante reserva de mão-de-obra para as grandes propriedades, as fazendas, e de centros irradiadores da Religião, da Administração e da Justiça, vêm-se de repente transformadas em pólos agenciadores de uma transformação estrutural, onde a moderna agroindústria e os serviços têm lugar de destaque. Nesse processo de modernização da agricultura, ocorrido em curtíssimo espaço de tempo e cujo início coincide com a alta considerável de preços dos produtos agrícolas no mercado mundial dos anos setenta, a implantação de uma nova tecnologia nesse domínio veio apenas assestar um golpe de misericórdia nos últimos bastiões da formação social tradicional da região: as pequenas sociedades locais dessas cidades históricas que cercam Brasília num anel singelo, de um passado, hoje, em esvanecimento.” (Pinto 1990, p.161)

Pelas suas características ecológicas, geopolíticas, demográficas, sócio-econômicas e culturais, o Cerrado é o bioma da integração nacional. A oferta ambiental é grande, e atrai muito pela diversidade de ambientes e condições de ocupação. Sobretudo antes mesmo da ocupação das terras próximas ao Distrito Federal, já existia ocupação nos estados de Goiás e de Minas Gerais, na parte ligada a região central do Cerrado.

“A procura de carvão vegetal para as siderúrgicas do Sul do Brasil motivou a conversão, em carvão, de enormes extensões de cerrados e o aparecimento de reflorestamento de Eucaliptus spp com esse fim. Também a geração de tecnologia para cultivar os solos ácidos dos cerrados, a proximidade dos grandes centros de consumo, o preço 
das terras mais baixos que nas regiões Sul e Sudeste do país, a boa aptidão física e topografia das terras e um clima monçônico com excelentes condições de pluviosidade e luminosidade fizeram com que a área agriculturada se expandisse a ritmos extremamente elevados.” (Pinto 1990, apud Goedert, 1986; Cochrane et al., 1984)

Em virtude de ser os solos pobres e ácidos, o desenvolvimento da agricultura só pode ser realizável com elevado consumo de corretivos da acidez e da fertilidade. Ao mesmo tempo, houve um esforço, ainda não concluído, de adaptar cultivos adaptados à região. Ainda é possível obter-se, com as modernas técnicas de biotecnologia, cultivos que exijam menos corretivos e diminuam o impacto nos solos.

De acordo com Pinto (1990), é possível a recuperação na perspectiva da sustentabilidade. Basta que para isso, se tenha suporte técnico, apoio institucional e parcerias.

“Reflorestamento para carvão vegetal, considerado que esse melhoramento pode ser obtido pela escolha de espécies apropriadas e, no caso de exóticas, pela escolha de procedência de sementes mais adaptáveis.

- Cultivo de espécies regionais:

Adaptação para o cultivo de espécies nativas da região como frutíferas, flora medicinal e pastagens. Os resultados que podem ser obtidos melhorariam bastante a diversidade de cultivos, e permitiriam adaptação maior, porque são espécies próprias da região e mais resistentes às condições naturais.

- Diversificação de culturas e pastagens:

É sabido que a monocultura em grandes extensões é extremamente vulnerável ao aparecimento e propagação de pragas. A prática da rotação de culturas e diversificação na horizontal favorece a conservação dos solos, melhora a capacidade do produtor de enfrentar dificuldades devido às oscilações dos preços, e desfavorece a transmissão de doenças.

Por enquanto os cerrados são ocupados, em grandes extensões, por culturas muito rentáveis como a soja e o arroz, mas o caminho racional é a diversificação a médio prazo.

- Controle de poluição hídrica:

Para efetivar o controle da poluição hídrica do Cerrado, deveriam ser realizadas várias atividades paralelas, como as descritas a seguir:

a) capacitação e reforço dos órgãos de controle;

b) reaproveitamento e/ou tratamento do vinhoto, que poderá ter o destino seguinte:

- concentração e combustão;

- produção de proteína celular;

- venda à fábrica de rações;

-tratamento biológico;

-tratamento físico-químico;

-utilização para destilação de álcool; 
-aplicação direta no solo;

c) controle de fontes poluidoras.

d)controle de uso de agrotóxicos.” (Pinto, 1990, p.571)

A região do Cerrado deve ser mais conhecida na sua diversidade paisagística, ecológica e humana. Deve-se ter o conhecimento mais detalhado, para que seja valorizado. Portanto, está vulnerável a qualquer tipo de destruição e precisando ter planejamento para sua maior proteção. Os cerrados são muito carentes de unidades de conservação bem instalados e com infra-estrutura que permita utilizá-los de uma forma que possa ter melhor conservação. As unidades de conservação que existem são desprotegidas e não são aproveitáveis para o turismo atualmente.

Uma das propostas do Ecomuseu do Cerrado é fazer em todos os municípios que o compõem, projetos que recuperem a vegetação nativa, na construção de hortos florestais, jardins botânicos, herbários de plantas medicinais para uso da comunidade, Museu do Cerrado e recuperação de áreas degradadas próximas as margens de rios, as áreas urbanas e rurais das cidades. Enfim, é trabalhar para restauração do cerrado no Planalto Central, com pesquisas e estudos técnicos preocupados na melhor maneira de realizar essa tarefa para compensar as perdas ao longo dos anos, visando melhor qualidade de vida.

Hoje há uma preocupação mundial com a representação de reservas ecológicas da biosfera, pois os números vêm aumentando, conforme os dados da Unesco (2000):

“Existem 391 reservas da biosfera, formando uma rede mundial na busca conjunta do desenvolvimento sustentável. A gestão das reservas da biosfera coloca no mesmo nível de importância as variáveis ambientais, culturais e socioeconômicas, respeitando as especificidades de cada reserva.

A Reserva da Biosfera do Cerrado no Distrito Federal foi reconhecida pela Organização das Nações Unidas - UNESCO em 1993 e engloba, na sua área nuclear, cerca de 50.000 ha protegidos: O Parque Nacional de Brasília (30.000), a Estação Ecológica de Águas Emendadas (10.500) e a Zona de Vida Silvestre da Área de Proteção Ambiental das bacias do Gama e Cabeça de Veado (10.000). Em torno desses números encontram-se as zonas de tampão e as zonas de transição que têm a função de proteção e de corredores ecológicos. Esta reserva tem como desafio conciliar a conservação da natureza com o bem-estar da população, englobando no seu todo 40\% do território do Distrito Federal.” (Vegetação no Distrito Federal, 2000, p.11) 


\section{2-LEGISLAÇÃO AMBIENTAL}

Sobre as leis que regem, visando a proteção ambiental em atividades que podem danificar a natureza, estão relacionadas a seguir:

Na Constituição Federal de 1988 Art. 225 - III - definir, em todas as Unidades de Federação, espaços territoriais e seus componentes a serem especialmente protegidos, sendo a alteração e a supressão permitidas somente através de lei, vedada qualquer utilização que comprometa a integridade dos atributos que justifiquem sua proteção;

VII - proteger fauna e a flora, vedadas, na forma da lei, as práticas que coloquem em risco sua função ecológica, provoquem a extinção de espécies ou submetam os animais a crueldade.

O Código Florestal de 15 de setembro de 1965, Lei 4.771 nos seus artigos 16 e 44, respectivamente, cita sobre áreas em proteção:

Art. 16. As florestas de domínio privado, não sujeitas ao regime de utilização limitada e ressalvadas as de preservação permanentes, previstas nos artigos $2^{\circ}$ e $3^{\circ}$ desta Lei, são suscetíveis de exploração, obedecidas as seguintes restrições:

a)as regiões Leste Meridional, Sul e Centro-Oeste, esta na parte sul, as derrubadas de florestas nativas, primitivas ou regeneradas, só serão permitidas desde que seja, em qualquer caso, respeitando o limite mínimo de $20 \%$ da área de cada propriedade com cobertura arbórea localizada, a critério da autoridade competente;

$\S 3^{\circ}$ - Aplica-se às áreas de cerrado a reserva legal de 20\% (vinte por cento) para todos os efeitos legais. (Parágrafo acrescentado pela Lei $n^{\circ} 7.803$ de 18/7/1989)

Art. 44. Na região Norte e na parte Norte da região Centro-Oeste enquanto não for estabelecido o decreto de que trata o art. 15, a exploração a corte raso só é permissível desde que permaneça com cobertura arbórea, pelo menos 50\% da área de cada propriedade. (Vide Medida Provisória nº 2.166-67, de 24 de agosto de 2001) 


\section{- Conservação x ocupação:}

Estimou-se, em projeções a partir de dados do IBGE, IBAMA, RADAMBRASIL, CIMI e EMPRAPA, que em 1990, aproximadamente 37\% da área do Bioma do Cerrado tinha perdido sua cobertura primitiva e, portanto sua flora e fauna, tinha sido ocupada por diferentes paisagens antrópicas: pastagens plantadas (metade), culturas temporárias (especialmente soja, milho e arroz), culturas perenes (especialmente eucalípto, pinheiro, manga e café), represamentos, áreas urbanas e áreas degradadas abandonadas (desmatamentos, garimpos, áreas decapeadas, pastos e roças abandonadas, voçorocas, lixos, etc). Esses 37\% de área com paisagem antrópica, basicamente mono ou oligoculturas exóticas, já que os efeitos da poluição hídrica, agrotóxicos, erosão/assoreamento, plantas e animais invasores e extrativismo vegetal e animal predatórios também se fez sentir nas áreas ainda cobertas de paisagem natural vizinhas.Várias espécies de plantas e animais nativos sobreviveram nas áreas de paisagem antrópica, porém tenderam a desaparecer por falta de preocupação com sua preservação.

Os estimados 63\% ainda cobertos por paisagens naturais foram basicamente constituídos por áreas privadas submetidas a diferentes intensidades de uso: a maior parte (67\%) foi manejada como pastagem nativa para criação de gado de corte (com média de uma cabeça/ha) e exploração de carvão vegetal, e pouco mais $1 / 5$ foi mantido como reserva florestal para exploração de madeira e lenha pó proteção de encostas e cursos d’água. Aproximadamente metade dessa floresta se enquadrou como Áreas de Preservação Permanente segundo o artigo $2^{\circ}$ do Código Florestal, Lei 4.771 de 07 de julho de 1986, ou Reservas Ecológicas segundo o artigo 18 da Lei 6.938 e Resolução $n^{\circ}$ 4/85 do CONAMA de 18 de setembro de 1985. Aproximadamente 9\% da Paisagem Natural Remanescente, foi composta por áreas indígenas, 1,1\% é declarada como Área de Proteção Ambiental e apenas 2,5\% são declaradas como preservação (parques, reservas científicas e monumentos naturais). (Pinto 1990, p.584)

Dados da Organização Não Governamental WWF do Brasil em 2003, informa que pela extensão territorial do Brasil permite que haja um mosaico de tipos de vegetação, solo, clima e topografia heterogêneos. O cerrado é a segunda maior formação vegetal brasileira, superado pela Floresta Amazônica, com aproximadamente 2 milhões de $\mathrm{Km}^{2}$ espalhados por 10 estados, 
ou 23,1\% do território brasileiro... Estudos recentes indicam que apenas cerca de $20 \%$ do cerrado ainda possui vegetação nativa em estado relativamente intacto.

Segundo referências do Ministério do Meio Ambiente em 2002, estão previstas áreas consideradas “Áreas Prioritárias para a Conservação da Vegetação em Goiás em localidades da: Região de Niquelândia, Serra dos Pirineus (Parque Estadual dos Pirineus), Chapada dos Veadeiros e adjacências, Norte do Distrito Federal (Fercal - Bacia do Rio Maranhão) e Cristalina.

Os resultados indicam que apenas 1/3 das áreas de cerrado do Brasil encontram-se pouco antropizadas. As principais regiões de grande impacto antrópico estão nos estados de Mato Grosso do Sul e de Goiás, de São Paulo, na divisa de São Paulo com Paraná, e no estado de Mato Grosso do Sul. Nestas áreas diversas imagens mostram de 50\% a 92\% da superfície de cerrado em condição fortemente antropizada.”

Vale ressaltar o quanto o cerrado vem sofrendo com a degradação a favor do desenvolvimento e crescimento das regiões. Isso faz reforçar a preocupação com o futuro do bioma e a maneira de como está sendo usado. Dados retratam que o número tem sido cada vez maior conforme o tempo vem passando, e é nessas horas que a reflexão é importante para ver atuação do homem com a natureza.

\section{4-ECOLOGIA PROFUNDA - UM NOVO PARADIGMA}

A verdade é que se não for modificado o nosso modo de ver a vida e como tratá-la, será mais trabalhoso recuperar danos que muitas vezes são provocados pela forma incorreta que manuseamos os problemas. Permitindo que valores sejam muitas vezes trocados a favor dos interesses imediatistas, debatemos em erros que são refletidos nos fenômenos apresentados na natureza. Portanto, cabe refletir sobre a transformação do ser, de ver o quê ainda pode ser feito para que o retrato seja revertido em benefícios para os seres do planeta. 
Hoje, a discussão sobre a percepção da ecologia profunda, faz com que possamos ter explicações dos problemas existentes no mundo e tentar mudar a ecologia interior. Manter o equilíbrio da vida é o grande desafio para o futuro que buscamos.

A respeito desse novo paradigma, Capra (1996), relata sobre essa nova maneira de percepção de ver a vida:

“Compreensão científica da vida em todos os níveis dos sistemas vivos - organismos, sistemas sociais e ecossistemas, baseia-se numa percepção da realidade, que tem profundas implicações não apenas para a ciência e para a filosofia, mas também para as atividades comerciais, a política, a assistência à saúde, a educação e a vida cotidiana. Portanto, é apropriado começar com um esboço do amplo contexto social e cultural da nova concepção de vida.

Defrontamo-nos com toda uma série de problemas globais que estão danificando a biosfera e a vida humana de uma maneira alarmante, e que pode logo se tornar irreversível. Temos ampla documentação a respeito da extensão e da importância desses problemas. São problemas sistêmicos que significam que estão interligados e são interdependentes."

"O reconhecimento de que é necessária uma profunda mudança e percepção e de pensamento para garantir a nossa sobrevivência ainda não atingiu a maioria dos líderes das nossas corporações, nem os administradores e os professores das nossas grandes universidades.

A partir do ponto de vista sistêmica, as únicas soluções viáveis são as soluções "sustentáveis". O conceito de sustentabilidade adquiriu importância-chave no movimento ecológico e é realmente fundamental. Lester Brown, do Worldwatch Institute, deu uma definição simples, clara e bela: "Uma sociedade sustentável é aquela que satisfaz suas necessidades sem diminuir as percepções das gerações futuras.” Este, em resumo, é o grande desafio do nosso tempo: criar comunidades sustentáveis - isto é, ambientes sociais e culturais onde podemos satisfazer as nossas necessidades e aspirações sem diminuir as chances das gerações futuras.” (Capra, 1996, p.23 e24)

O termo holístico, não vê o mundo formado por partes, não vê o homem como o ser supremo e sim, como um elemento do mundo:

“O novo paradigma pode ser chamado de uma visão de mundo holístico, que concebe o mundo como um todo integrado, e não como uma coleção de partes dissociadas. Pode ser também denominados visão ecológica, se o termo "ecológica" for empregado num sentido muito mais amplo e profundo que o usual. A percepção ecológica profunda reconhece a interdependência fundamental de todos os fenômenos, e o fato de que, enquanto indivíduos e sociedades, estamos encaixados nos processos cíclicos da natureza e, em última análise, somos dependentes desses processos.” (Capra, 1996, p.24) 
O sentido do termo “ecológico” usado por Capra (1996) está associado com uma escola filosófica específica, e além disso, com um movimento popular global conhecido como “ecologia profunda”. A escola filosófica foi fundada pelo filósofo norueguês Arne Naess, no início da década de 70, com sua distinção entre “ecologia rasa”e “ecologia profunda”.

“A ecologia rasa ${ }^{5}$ é antropocêntrica, ou centralizada no ser humano. Ela vê os seres humanos como situados acima ou fora da natureza, como a fonte de todos os valores, e atribui apenas um valor instrumental, ou de “uso”, à natureza. A ecologia profunda não separa seres humanos - ou qualquer outra coisa - do meio ambiente natural. Ela vê o mundo não como uma coleção de objetos isolados, mas como uma rede de fenômenos que estão fundamentalmente interconectados e são interdependentes. A ecologia profunda reconhece o valor intrínseco de todos os seres vivos e concebe os seres humanos apenas como um fio particular na teia da vida. Em última análise, a percepção da ecologia profunda é percepção espiritual ou religiosa.

Há outro modo pelo qual Arne Naess caracterizou a ecologia profunda. “A essência da ecologia profunda, consiste em formular questões mais profundas.” É também essa essência de uma mudança de paradigma. Portanto, a ecologia profunda faz perguntas profundas a respeito dos próprios fundamentos da nossa visão de mundo e do nosso modo de vida modernos, científicos, industriais, orientados para o crescimento e materialistas.

Além da ecologia profunda, há duas importantes escolas filosóficas de ecologia, a ecologia social e a ecologia feminista, ou "ecofeminismo".

A percepção ecológica profunda parece fornecer a base filosófica e espiritual ideal para um estilo de vida ecológico e para o ativismo ambientalista. No entanto, não nos diz muito a respeito das características e dos padrões culturais de organização social que produziram a atual crise ecológica. É esse o foco da ecologia social.

\footnotetext{
${ }^{5}$ Dados retirados do livro: CAPRA, Fritjof. “A teia da vida: uma nova compreensão científica dos sistemas vivos”. Ed. Cultrix - SP,
} 
A mudança de paradigmas requer uma expansão não apenas de nossa percepções e maneiras de pensar, mas também de nossos valores. É interessante notar a conexão nas mudanças entre pensamento e valores. Ambas podem ser vistas como mudanças da auto-afirmação para a integração. Ambas são aspectos essenciais de todos os sistemas vivos. O que é bom, ou saudável, é o equilíbrio dinâmico; o que é mau, ou insalubre, é o desequilíbrio.

A mudança de paradigma inclui uma mudança na organização social, uma mudança de hierarquias para redes.

Toda a questão dos valores é fundamental para a ecologia profunda; é, de fato, sua característica definidora central. Enquanto que o velho paradigma está baseado em valores antropocêntricos (centralizados no ser humano), a ecologia profunda está alicerçada em valores ecocêntricos (centralizados na Terra). É uma visão de mundo que reconhece o valor inerente da vida não-humana. Todos os seres vivos são membros de comunidades ecológicas ligadas umas às outras numa rede de interdependências. Quando essa percepção ecológica profunda torna-se parte de nossa consciência cotidiana, emerge um sistema de ética radicalmente nova.

Entender as coisas sistematicamente significa, literalmente, colocá-las dentro de um contexto, estabelecer a natureza de suas relações. O bioquímico Laurence Henderson, foi influente no seu pioneiro termo "sistema" para denotar tanto organismos vivos como sistemas sociais. Dessa época em diante, um sistema passou a significar um todo integrado cujas propriedades essenciais surgem das relações entre suas partes, e "pensamento sistêmico”, a compreensão de um fenômeno dentro do contexto de um todo maior.

Enquanto os biólogos organísmicos encontravam uma totalidade irredutível nos organismos, os físicos quânticos em fenômenos atômicos e os psicólogos da Gestalt na percepção, os ecologistas a encontravam em seus estudos sobre comunidades animais e vegetais. A nova ciência da ecologia emergiu da escola organísmica de biologia durante o século XIX, quando os biólogos começaram a estudar comunidades de organismos. 
A ecologia - palavra proveniente do grego oikos (“lar”) - é o estudo do Lar Terra. É o estudo das relações que interligam todos os membros do Lar Terra. O termo foi introduzido em 1866 pelo biólogo alemão Ernest Haeckel, que o definiu como a ciência das relações entre o organismo e o mundo externo circunvizinho. Em 1909, a palavra Umwelt (“meio ambiente”) foi utilizada pela primeira vez pelo biólogo e pioneiro da ecologia do Báltico Jacob von Uexküll e Frederic Clement, um ecologista de plantas norte-americano e pioneiro no estudo da descendência, concebia as comunidades vegetais como "supeorganismos”. Essa concepção desencadeou um vivo debate, que prosseguiu por mais de uma década, até que o ecologista de plantas britânico A.G. Tansley rejeitou a noção de superorganismos e introduziu o termo “ecossistema” - definida hoje como uma comunidade de organismos e suas interações ambientais físicas como uma unidade ecológica - moldou todo o pensamento ecológico subseqüente e, com seu próprio nome, promoveu uma abordagem sistêmica da ecologia.

O Sistema Gaia pode ser descrito como uma rede autopoiética, vamos aplicar três critérios propostos por Gail Fleischaker. Gaia é, autolimitada... a atmosfera da Terra é criada, transformada e mantida pelos processos metabólicos da biosfera ... É autogerador ... Todos os componentes da rede de Gaia, incluindo aqueles de sua fronteira atmosférica , são produzidos por processos internos à rede ... É autoperpetuante. Os componentes dops oceanos, do solo e do ar, bem como todos os organismos da biosfera, são continuamente repostos pelos processos planetários de produção e de transformação.

Na emergente teoria dos sistemas vivos, a mente não é uma coisa, mas um processo. É a cognição, o processo do conhecer, e é identificada com o processo da própria vida. É esta a essência da teoria da cognição de Santiago, proposta por Humberto Maturama e Francisco Varela.

A identificação da mente, ou cognição, como processo da vida é uma idéia radicalmente nova na ciência, mas também uma das intuições mais profundas e mais arcaicas da humanidade. 
A antiga intuição comum que está por trás de todas essas palavras é a da alma ou espírito como o sopro da vida. De maneira semelhante, a concepção de cognição na teoria de Santiago vai muito além da mente racional, pois inclui todo o processo da vida.

Notamos a tensão básica entre o desafio da sustentabilidade ecológica e a maneira pela qual nossas sociedades atuais estão estruturadas, a tensão entre economia e a ecologia. A economia enfatiza a competição, a expansão e a dominação; ecologia enfatiza a cooperação, a conservação e a parceria.

Os princípios da ecologia - a interdependência , o fluxo cíclico de recursos, a cooperação e a parceria - são, todos eles, diferentes aspectos do mesmo padrão de organização... Existe mais dois princípios da ecologia - flexibilidade e diversidade - que permitem que os ecossistemas sobrevivam às perturbações e se adaptem a condições mutáveis.

Nos ecossitemas, a complexidade da rede é uma conseqüência da sua biodiversidade e desse modo, uma comunidade ecológica diversificada é uma comunidade elástica. Nas comunidades humanas, a diversidade étnica e cultural pode desempenhar o mesmo papel. Diversidade significa muitas relações diferentes, muitas abordagens diferentes do mesmo problema. Uma comunidade diversificada é uma comunidade elástica, capaz de se adaptar a situações mutáveis.

No entanto, a diversidade só será uma vantagem estratégica se houver uma comunidade realmente vibrante, sustentada por uma teia de relações. Se a comunidade estiver fragmentada em grupos e em indivíduos isolados, a diversidade poderá, facilmente, tornar-se uma fonte de preconceitos e de atrito.

São alguns princípios básicos da ecologia - interdependência, reciclagem, parceria, flexibilidade, diversidade e, como conseqüência de todos estes, sustentabilidade... A sobrevivência da humanidade dependerá de nossa alfabetização ecológica, da nossa capacidade para entender esses princípios da ecologia e viver em conformidade com eles.” 


\section{5-Materiais e Métodos}

O presente trabalho foi realizado por meio de pesquisa bibliográfica e entrevistas abertas com a coordenadora do Ecomuseu do Cerrado Prof ${ }^{\text {a }}$ Laís Aderne e com o Prof. Manoel Cláudio Da Silva Júnior da UnB, que participa efetivamente com projetos e trabalhos acadêmicos para o Ecomuseu do Cerrado.

Foram realizadas também, visitas aos seguintes municípios:

- Corumbá de Goiás/GO primeiramente, em uma reunião com a comunidade local e com participantes de outros municípios que fazem parte do Ecomuseu, na qual foram apresentados e discutidos projetos que visam a melhoria ambiental e cultural de forma sustentável de cada localidade.

- Pirenópolis/GO com um grande número de participantes da sociedade civil e instituições governamentais federais e municipais, a qual teve como meta primordial, a construção da Agenda 21 Municipal.

- Santo Antônio do Descoberto/GO, com a apresentação de levantamentos sociais, físicos, econômicos e culturais que visassem a elaboração de projetos para a construção da Agenda 21 do local.

A partir desses encontros, palestras assistidas e das informações adquiridas, foi iniciado o trabalho com a proposta de verificar a possibilidade da implementação do ecoturismo nos municípios que compõem o Ecomuseu do Cerrado.

\section{6-Resultados e Discussão}

O ecoturismo é uma atividade econômica, dentro dos preceitos de desenvolvimento sustentável, que pode oferecer recursos financeiros que garantirão benefícios para a comunidade local valorizando o seu potencial e, ao mesmo tempo, conscientizando-a da necessidade de reversão destes recursos para a proteção da biodiversidade do cerrado, criação de curso de educação ambiental e a preservação da natureza obedecendo a legislação ambiental do país, tendo em vista o uso e a ocupação do solo. 
O Ecomuseu do Cerrado é o objeto que pode contribuir para o ecoturismo da região, mesmo com todos os problemas existentes hoje.

\section{7-Propostas}

Como proposta de trabalho, verifiquei que o Ecomuseu do Cerrado tem perfil para o ecoturismo e tratei como instrumento de estudo para a realização da monografia que é um dos critérios obrigatórios para a finalização do curso de Pós-graduação em Ecoturismo.

\section{8- Considerações Finais}

O aumento geométrico da população humana resulta no uso indiscriminado das riquezas naturais. Com o processo de ocupação do espaço territorial do planeta Terra, o homem compete com os outros seres, por espaço e recursos e a conseqüência é a utilização desordenada da natureza. Tal fato tem gerado conflitos sociais e ambientais, principalmente porque de um lado, o homem tem na sua essência o egocentrismo e pelo outro, o próprio sistema econômico e político do mundo, faz com que haja competição e disparidade para a sobrevivência.

Esses anseios têm se tornado a realidade da humanidade, que responde na atualidade de forma cada vez mais egoísta em sua convivência. O resultado é a comunicação virtual em nome da globalização, a preferência ao isolamento, tornando o indivíduo cada vez mais solitário, com comportamento arredio quanto ao que possa ser compartilhado com o outro. Isso, e tantos outros modos da vida moderna, estão modificando os valores, os conceitos e as percepções da humanidade. Está chegando o momento em que se torna necessária a reflexão quanto aos paradigmas e as relações da humanidade com o planeta Terra.

Conforme Capra (1996, p.24), "há soluções para os principais problemas de nosso tempo, algumas delas até mesmo simples. Mas requerem uma mudança radical em nossas percepções, no nosso pensamento e nos nossos valores”. 
Pensar, planejar e executar ações que visem a compatibilização do bem-estar da humanidade com a adequada utilização dos bens naturais é produto da preocupação de qual herança será deixada para os futuros habitantes do planeta. Isso é conseqüência das transformações da ecologia interior e exterior do homem, o que permitirá melhorias na relação homem-ambiente em busca do modo de vida harmônico e equilibrado.

Portanto, o presente trabalho gerou expectativa, teve significado importante para abrangência do conhecimento científico, como também, proporcionou reflexão sobre a possibilidade de criar mecanismos que possam valorizar patrimônios. O Ecomuseu do Cerrado: um instrumento para o ecoturismo no Brasil Central, considera e permite que sejam desenvolvidos projetos que envolvam tal atividade, desfrutada por visitantes que buscam a percepção do novo e do desconhecido, baseados em roteiros turísticos de cunho ambiental, histórico e cultural, como também, locais que apresentam belezas cênicas, trilhas ecológicas, culinárias, artesanatos, educação ambiental, planejamentos preocupados com a sustentabilidade que promove a participação econômica, política, social e cultural do seu povo. 


\section{9-REFERÊNCIA BIBLIOGRÁFICA}

1-“Almanaque Ecomuseu do Cerrado”, 2002.

2-BARRETTO, Margaritta. “Turismo e Legado Cultural: as possibilidades do planejamento”. São Paulo: Papirus, $4^{\text {a }}$ edição, 2003.

3-“Biodiversidade Brasileira - Avaliação e identificação de áreas e ações prioritárias para a conservação, utilização sustentável e repartição dos benefícios da biodiversidade nos biomas brasileiros.” Brasília: Ministério do Meio Ambiente - MMA/SBF, 2002.

4-Caderno Técnico: "Prevenção e Combate aos incêndios florestais em Unidades de Conservação”. Governo do Distrito Federal - GDF. Secretaria de Meio Ambiente e Recursos Hídricos do Distrito Federal - SEMARH. Brasília: Athalaia Gráfica e Editora, 2004.

5-CAPRA, Fritjof. “A teia da vida: uma nova compreensão científica dos Sistemas Vivos”. São Paulo: Cultrix, 1996.

6-FARIA, Doris Santos de e CARNEIRO, Kátia Saraiva. "Sustentabilidade Ecológica no Turismo”. Brasília: Editora Universidade de Brasília, 2001.

7-FENNELL, David A. “Ecoturismo: uma introdução”. São Paulo: Contexto, 2002.

8-IRVING, Marta de Azevedo e Júlia Azevedo. “Turismo: o desafio da sustentabilidade”. São Paulo: Futura, 2002.

9-NÓBREGA, Ricardo Campos da. “Áreas prioritárias para a conservação da biodiversidade no âmbito do projeto Ecomuseu do Cerrado”. Dissertação de mestrado em Ciências Florestais, Brasília: UNB, 2002. 
10-PINTO, Maria Novaes (Org.). “Cerrado: caracterização, ocupação e perspectivas”. Brasília: UNB, 1990.

11-RIZZINI, Carlos Toledo, FILHO, Ademar F. Coimbra e HOUAISS, Antônio.”Ecossistemas Brasileiros”. Enge-RIO, Engenharia e Consultoria S.A. Editora Index, 1988.

12-“Vegetação no Distrito Federal - tempo e espaço”. Brasília: UNESCO, 2000.

13-SCHEINER, Tereza Cristina. Seminário “Museus na virada do Século”. Palestra: Educação Ambiental em Museus. Brasília: Teatro Nacional Cláudio Santoro, 20 de setembro de 1997.

Sites:

www.lagazzettaweb.it, acesso em 25 de julho de 2004.

www.ecomusei.net, acesso em 25 de julho de 2004.

www.revistamuseu.com.br, acesso em 21 de julho de 2004.

www.mma.gov.br, acesso em 20 de julho de 2004.

www.estadão.com.br, acesso em 31 de maio de 2004.

www.planalto.gov.br, acesso em 19 de novembro de 2003. 
10 - ANEXOS

Anexo A

Mapa Político do EcoMuseu do Cerrado

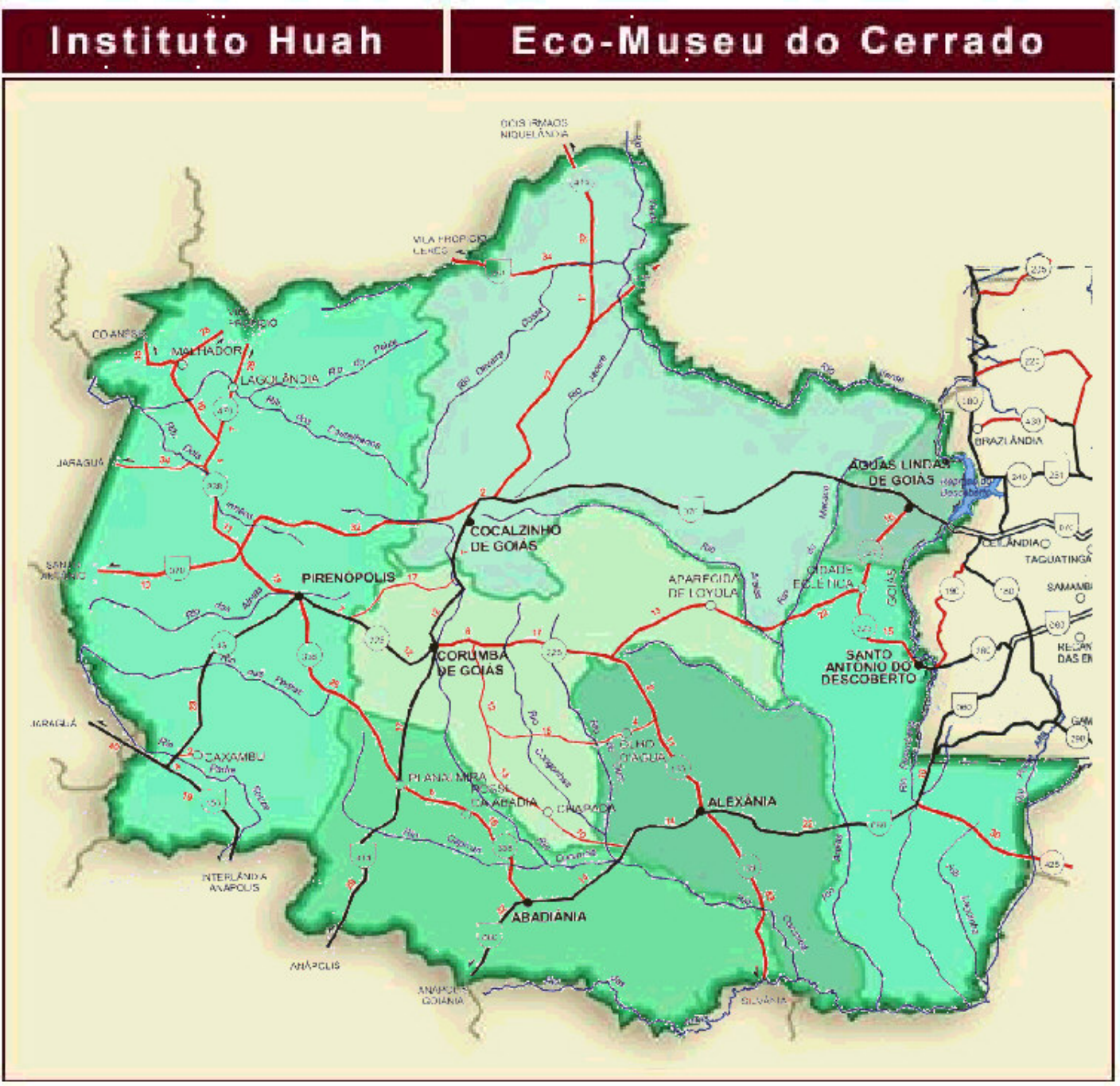




\section{Anexo B \\ ENTREVISTA COM LAÍS ADERNE EM 17 DE JULHO DE 2004 ÀS 9 HORAS:}

O Ecomuseu do Cerrado é um museu aberto, que trabalha pela preservação do patrimônio natural e cultural do ecossistema do cerrado do Planalto Central e todos os seres vivos que o habitam.

Nós não começamos o projeto do Ecomuseu pelo museu fechado, estamos fazendo um processo inverso, buscando preservar, resgatar e valorizar os monumentos naturais e culturais destes $8.066 \mathrm{Km}^{2}$, desde seu subsolo com as rochas e suas reservas aqüíferas até sua cobertura vegetal e animal e sua cultura material e imaterial... As edificações, a música, a poesia, as cavalhadas, os saraus, serestas e feiras, as comidas típicas, as tecnologias, o artesanato e todos os pensares e fazeres culturais.

Nossa primeira etapa de trabalho foi dedicada aos cursos, oficinas, seminários - feiras e festas, escoamento da produção cultural, procurando integrar ações com o poder público e a sociedade organizada e realizar um planejamento conjunto e as ações possíveis, com a formação das Brigadas de Incêndio, dos Núcleos de Informação, eventos educativos e culturais e publicações.

Nossa segunda etapa, bastante prejudicada pela falta de recursos financeiros, foi investir nas micro-regiões onde o acesso ao poder público e às populações fosse mais difícil. Para tanto recorremos às metodologias mais simples, já utilizadas no início de nossa jornada na região, há 32 anos, no povoado de Olhos d’Água, município de Alexânia. Para alcançar esses objetivos criamos os subprojetos: "Replantando a Vida no Cerrado" e "Circuito das Feiras e Festas de Cultura do Cerrado” no ano de 2002/3 e nasceram as gincanas, para coletas de mudas e sementes de árvores nativas, com as crianças das escolas de Santo Antônio do 
Descoberto e Corumbá. Nasceram também neste período a Feira dos Poetas, Escritores e Músicos de Corumbá e a Feira da Vida no Cerrado, em Santo Antônio do Descoberto. Esses dois eventos tiveram resultados muito bons e estão continuando com sua $2^{\mathrm{a}}$ edição em 2004.

Dessa etapa nasceu o grupo de Mulheres de Corumbá, que resgatou histórias da região e músicas antigas, abrindo os baús e resgatando também memórias dos fazeres culturais, como bordados, tecidos, objetos, partituras e escritos do passado. Essas mulheres criaram o grupo de seresta “Cantantes do Luar" que integra vozes femininas e masculinas e homens instrumentalistas.

Em 2004 estamos em nossa $3^{\text {a }}$ etapa de trabalho, com a criação de um programa de recuperação de áreas degradadas nos sete municípios que integram a área do Ecomuseu: Águas Lindas, Alexânia, Cocalzinho, Corumbá, Pirenópolis e Santo Antônio do Descoberto. Este programa dará continuidade ao projeto "Replantando a Vida do Cerrado", com as escolas dos municípios e trabalhará, também, com os professores de geografia, história, biologia e artes de maneira mais específica, para iniciar neste ano a preparação de sua ação mais ampla em 2005, envolvendo as escolas. Essa ação receberá apoio da Universidade do Cerrado, que está nascendo. Os primeiros cursos a serem implantados serão: “Ecologia Ambiental, Humana e Social”, “Normal Superior” com introdução de conteúdos de Ecologia Humana, Ambiental e Social, Cultura e Sociedade e curso superior de “Artes Visuais, Cênicas e Música”.

Para implantação dessa Universidade do Cerrado e da Sede do Ecomuseu, com o Museu de História Natural, voltado para o Bioma Cerrado, estamos preparando, para o próximo mês de agosto, um encontro de reflexão sobre os temas: Ecologia Humana, Ambiental e Social, Cultura e Sociedade, que contará com a presença de especialistas brasileiros e de outros países Latino Americano e da América do Norte. Esse Encontro pretende reunir professores, ambientalistas, ecólogos, administradores e outros interessados dos municípios de Goiás e também do Distrito Federal, integrando também os Conselhos Locais do Ecomuseu e os Fóruns da Agenda 21 local, que se formaram nas regiões. 
A proposta do Museu de História Natural de nosso bioma no planalto central incluirá a natureza de nossa geologia, vegetação, fauna, o homem e a história da região com seus aspectos sociológicos e antropológicos, enfatizando nossa identidade cultural.

O visitante, através do conhecimento adquirido, será levado a se interessar por conhecer cada vez mais o museu vivo do cerrado e seus monumentos naturais e culturais. Para tanto temos os estudos realizados como o "Roteiros e Trilhas do Ecomuseu" de Bismarque Villa Real, um estudo financiado pela Secretaria Estadual de Meio Ambiente que deverá subsidiar os programas de visitas, do futuro Centro de Turismo Ecológico.

Alguns problemas como a questão de resíduos sólidos, que já foi tratado em Seminário com especialistas da Universidade de Viçosa, São Paulo e Goiânia, (financiado pelo IBAMA, no primeiro convênio firmado), ainda não tem solução. A falta de recursos, no período posterior ao Seminário, não permitiu a realização do diagnóstico necessário. Entretanto, a Dra. Lenita Nicoletti da FIOCRUZ, que participou do evento, já defendeu uma tese de doutorado abordando o assunto. Esta tese seguramente apoiará as ações futuras nessa área, quando encontrarmos os parceiros necessários para financiar as ações e derem soluções à questão de forma integrada na região.

Nosso I Encontro das Brigadas de Incêndio, foi em Abadiânia, quando a coordenação regional do Ecomuseu estava lá. Realizou-se na Chácara de Frei “Mateus Rocha”, Emaús, com apoio do Prev-Fogo, do IBAMA. Esse encontro possibilitou o contato com todos os indivíduos e grupos que já tinham alguma ação nos diversos municípios, nessa área, favorecendo a troca de experiências e o nascimento de uma posição consensual sobre o fogo no cerrado e quais as medidas a serem tomadas, num planejamento com a participação de todos.

Decidiu-se a formação das Brigadas de Voluntários em cada município e foram feitas outras parcerias, com o Corpo de Bombeiros de Goiânia e grupos da região: Pirenópolis e Santo Antônio. A primeira Brigada foi formada em Pirenópolis, onde o Corpo de Bombeiros manteve o equipamento. As de Corumbá e Cocalzinho foram formadas em conjunto, depois Santo Antônio do Descoberto e Águas Lindas, e por último, as de Abadiânia e Alexânia, que 
também foram formadas em conjunto. Cada uma com suas características próprias, com seus equipamentos próprios e acertos e erros. Considero que talvez a de Cocalzinho e a de Santo Antônio do Descoberto, sejam as duas que tenham maior organização e desempenho. A Brigada de Águas Lindas chegou a funcionar muito bem, inclusive, a Iolanda Cavalcante, como coordenadora, conseguiu que houvesse uma Lei Municipal que dava suporte aos brigadistas com jetons, no período do fogo.

Em Águas Lindas, o Corpo de Bombeiro de Goiânia deu suporte e houve ações integradas entre esse grupo e o de Santo Antônio do Descoberto.

Um princípio do Ecomuseu tem sido sempre um trabalho muito ligado à formação de recursos humanos, que tem como exemplo o primeiro que foi a realização do Seminário e Oficina que nós fizemos foi sobre a Biodiversidade. O segundo, foi Educação Ambiental, depois o de Brigadas de Incêndio e de Resíduos Sólidos. 